\title{
Effect of increased energy in a restricted diet on bone mineral composition and breaking load of young rat tibias
}

\author{
Marcia Ann Romanchak \\ West Virginia University
}

Follow this and additional works at: https://researchrepository.wvu.edu/etd

\author{
Recommended Citation \\ Romanchak, Marcia Ann, "Effect of increased energy in a restricted diet on bone mineral composition and \\ breaking load of young rat tibias" (2002). Graduate Theses, Dissertations, and Problem Reports. 1495. \\ https://researchrepository.wvu.edu/etd/1495
}

This Thesis is protected by copyright and/or related rights. It has been brought to you by the The Research Repository @ WVU with permission from the rights-holder(s). You are free to use this Thesis in any way that is permitted by the copyright and related rights legislation that applies to your use. For other uses you must obtain permission from the rights-holder(s) directly, unless additional rights are indicated by a Creative Commons license in the record and/ or on the work itself. This Thesis has been accepted for inclusion in WVU Graduate Theses, Dissertations, and Problem Reports collection by an authorized administrator of The Research Repository @ WVU. For more information, please contact researchrepository@mail.wvu.edu. 
Effect Of Increased Energy In A Restricted Diet On Bone Mineral Composition And Breaking Load Of Young Rat Tibias

\author{
Marcia A. Romanchak \\ Thesis Submitted to the \\ College of Agriculture, Forestry, and Consumer Sciences \\ at West Virginia University \\ in partial fulfillment of the requirements \\ for the degree of \\ Master of Science \\ in \\ Family and Consumer Sciences \\ M.Z.A. Nomani, Ph.D., R.D., Chair \\ Devinder Bhumbla, Ph.D. \\ Cindy Fitch, Ph.D., R.D. \\ Betty Forbes, M.A., R.D., L.D. \\ Division of Family and Consumer Sciences
}

Morgantown, West Virginia 2002

Keywords:Breaking Load, Rat Tibia, Bone Mineral Composition, Restricted Diet, Increased Energy 


\title{
ABSTRACT \\ Effect Of Increased Energy In A Restricted Diet On Bone Mineral Composition And Breaking Load Of Young Rat Tibias
}

\author{
Marcia A. Romanchak
}

Osteoporosis is a major health problem in the United States and those that are on energy restricted diets such as anorectic subjects. Thirty Wistar strain, young male rats were fed diets with varying quantities of fat for a period of four weeks (energy intake $67-75 \%$ of requirement). The rat tibias' physical properties were measured. Bone mineral composition testing was conducted for calcium, magnesium, and phosphorus, on the tibia shaft. There were no significant differences among the parameters of length, diameter, volume, density, bone bending (elasticity), fracture load, and minerals between experimental diets. There was a negative association between bending and bone density $(\mathrm{r}-0.48, \mathrm{p}<0.01)$. Density was also positively associated with calcium, magnesium, and phosphorus in the tibia shaft ( $\mathrm{r} 0.83,0.87,0.93$, respectively, $\mathrm{p}<0.01)$ per unit volume $(\mathrm{p}<0.01)$. Further studies on energy supplementation along with calcium and vitamin $\mathrm{D}$ under energy restricted conditions are suggested. 


\section{ACKNOWLEDGEMENTS}

The author wishes to express sincere thanks and appreciation to the graduate committee members:

Dr. M. Zafar A. Nomani, advisor and chair, for his instruction, assistance, and guidance throughout her academic career.

Dr. Bhumbla for his assistance with some of the technical aspects of the experiment and for serving as a committee member.

Dr. Cindy Fitch for her constructive advice and assistance and for serving as a committee member.

Professor Betty A. Forbes for her support throughout the author's academic career and for serving as a committee member.

Special thanks to:

The Division of Family and Consumer Sciences especially Joy Patterson, Shirley Robinson, Linda Kent, Nancy Conaway-Deiger, graduate students, and fellow dietetic interns.

The Department of Orthopedics especially Dr. Timothy Norman, Nina Clovis, Vince Kish, and Suzanne Smith.

Wendy Igo and Bharpoor Sekhon from the Department of Plant and Soil Sciences.

Tammy Webster from the Animal Science Department.

Dr. Andy Katayama for his assistance with the thesis manuscript.

Mindy Weaver for her counsel and advice.

Friends for their support and encouragement especially Bill Moore, Stephanie Goddard, Rachel Stewart, and Susannah Price.

The author's parents and sister for their love, patience, continuous guidance, support, and encouragement throughout the project and her academic career. 


\section{TABLE OF CONTENTS}

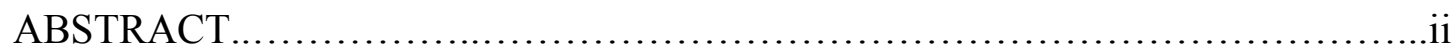

ACKNOWLEDGEMENTS ....................................................

TABLE OF CONTENTS ........................................................

LIST OF TABLES..............................................................

LIST OF FIGURES .........................................................

LIST OF ABBREVIATIONS ...............................................ii

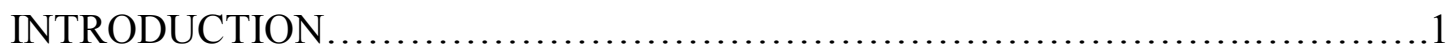

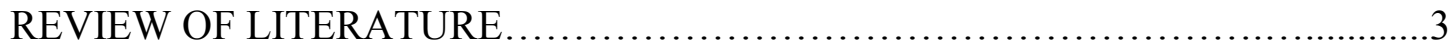

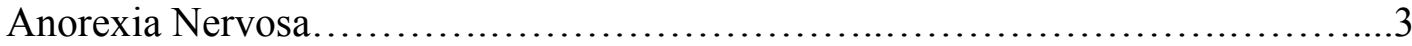

Ramadan Fasting........................................................ 6

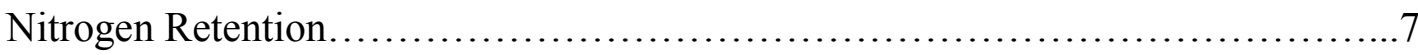

Effect of Fatty Acids on Bone Formation.................................... 9

Fat and Calcium Absorption................................................. 10

Energy Restriction and Bone Density ......................................11

Dietary Fat and Mineral Metabolism........................................... 14

Fat and Bone Strength......................................................... 16

Bone Turnover Rate at Different Levels of Dietary Protein Intake..................17

Effect of High Ratio of Animal to Vegetable Protein on Bone Loss....................17

Dietary Protein Intake and Bone Mass....................................... 18

Effect of Dietary Protein on Bone Loss in Elderly Men..............................20

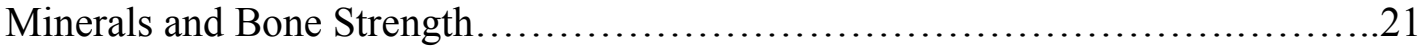

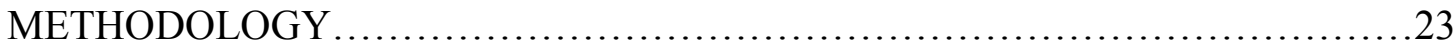

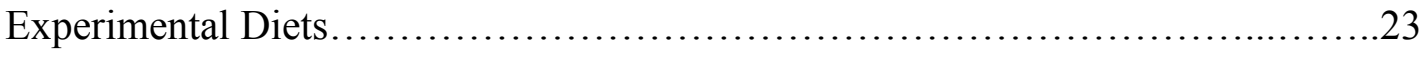

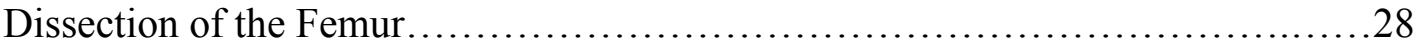

Tibia and Forelimb Dissection and Cleaning.................................... 28

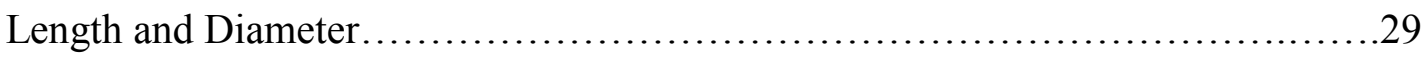

Weight of Whole Bone and Parts of Bone.........................................31

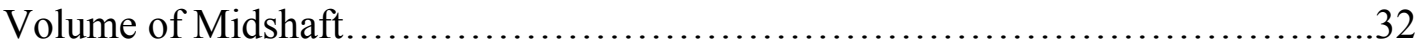


Fracture Load Testing.................................................. 32

Dry Matter Measurement............................................... 33

Wet Digestion.................................................... 34

Composition Analysis................................................. 35

Statistical Analysis....................................................... 35

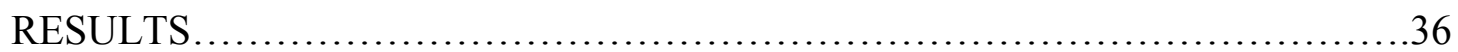

DISCUSSION ....................................................... 50

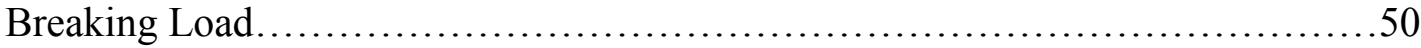

Density and Displacement............................................. 51

Summary and Conclusions ...........................................52

REFERENCES .......................................................... 53

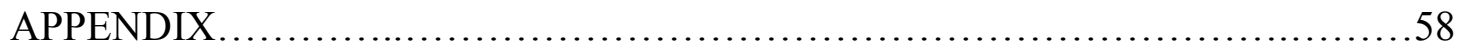

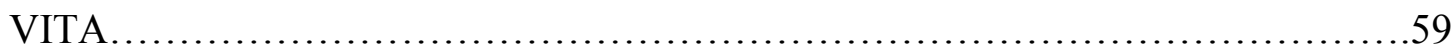




\section{LIST OF TABLES}

Table 1: Composition of Basal Diet............................................25

Table 2: Quantities of Experimental Diets Provided....................................26

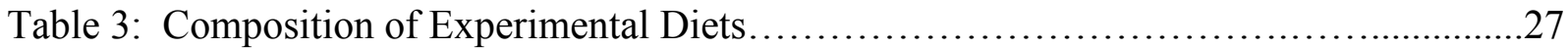

Table 4: Physical Properties of the Tibia with Experimental Diets......................... 37

Table 5: Physical Properties of the Tibia (shaft) with Experimental Diets...................38

Table 6A: Total Mineral Content of Tibia Shafts with Experimental Diets...................39

Table 6B: Mineral Content Per Gram Bone Basis of Shafts with Exp. Diets.................39

Table 6C: Mineral Content Per Unit Volume Basis of Shafts with Exp. Diets...............40

Table 7: Association Between Nitrogen Excretion and Bone Mineral Comp................41

Table 8: Association Between Bone Mineral Comp. and Shaft Breaking Load................41

Table 9: Association Between Bone Mineral Comp. and Bone Stiffness...................41 


\section{LIST OF FIGURES}

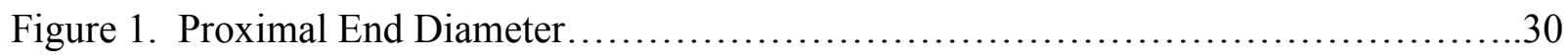

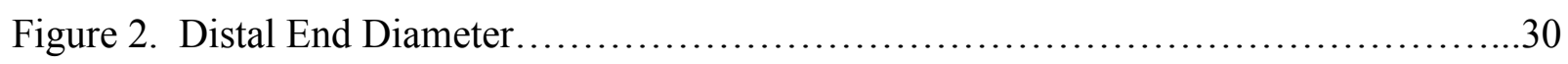

Figure 3. Midshaft Diameter...................................................... 31

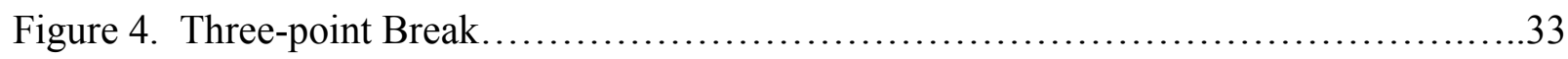

Figure 5. Displacement..................................................... 33

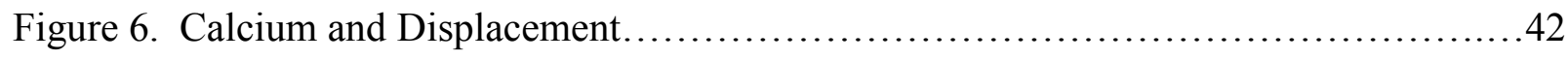

Figure 7. Magnesium and Displacement........................................ 43

Figure 8. Phosphorus and Displacement........................................ 44

Figure 9. Density and Displacement........................................... 45

Figure 10. Calcium and Density..............................................46

Figure 11. Magnesium and Density .......................................... 47

Figure 12. Phosphorus and Density............................................ 48

Figure 13. Model..........................................................49

Figure 14. Sites of bone end removal...........................................50

Figure 15. Suggestions for sites of bone separation for future studies.....................51 


\section{LIST OF ABBREVIATIONS}

\begin{tabular}{|c|c|}
\hline ANOVA & Analysis of variance \\
\hline AN & Anorexia Nervosa \\
\hline BMI & Body Mass Index \\
\hline BMD & Bone Mineral Density \\
\hline $\mathrm{BMC}$ & Bone Mineral Composition \\
\hline $\mathrm{BN}$ & Bulimia Nervosa \\
\hline $\mathrm{Ca}$ & Calcium \\
\hline $\mathrm{mm}^{3}$ & Cubic millimeters \\
\hline${ }^{\circ} \mathrm{C}$ & Degrees Celsius \\
\hline${ }^{\circ} \mathrm{F}$ & Degrees Fahrenheit \\
\hline g & Gram \\
\hline HDL & High density lipoprotein \\
\hline IU & International Units \\
\hline kcal & Kilocalorie \\
\hline $\mathrm{Kg}$ & Kilogram \\
\hline LDL & Low density lipoprotein \\
\hline $\mathrm{Mn}$ & Manganese \\
\hline $\mathrm{mg}$ & Milligram \\
\hline $\mathrm{mL}$ & Milliliter \\
\hline $\mathrm{nm}$ & Nanometers \\
\hline ppm & Parts per million \\
\hline $\mathrm{P}$ & Phosphorus \\
\hline RDA & Recommended Dietary Allowance \\
\hline
\end{tabular}




\section{INTRODUCTION}

Osteoporosis is a major health problem in the United States and the role of diet in its cause and prevention is currently being investigated (Kerstetter et al., 1999). Osteoporosis is a reduction in bone mass that can interfere with the mechanical support function of the bone (Thomas, 1989). Bone turnover and mineral metabolism are affected by a variety of factors including high levels of dietary protein, lack of dietary calcium, and energy restriction (Kerstetter et al., 1999; Talbott et al., 1998). Those with eating disorders such as anorexia nervosa or eating energy restricted diets are at risk for developing osteoporosis (Riggotti et al., 1991). Decreased cortical and trabecular bone mass has been observed in both women and men with anorexia nervosa and is associated with skeletal fractures (Riggotti et al., 1984).

Bone consists of a collagen matrix into which calcium is deposited. Bone is maintained by the continuous process of formation and resorption. The process of formation is predominant during childhood and adolescence allowing for an increase in bone mass and size. Peak bone mass is achieved shortly after completion of puberty. Osteoporosis is a deterioration of bone tissue leading to bone fragility and susceptibility to fractures and is the most common metabolic bone disorder in adults. While osteoporosis has usually been considered an adult disease, there is increasing evidence that what occurs in childhood may affect adult bone health. Failure to achieve peak bone mass as a child can have ramifications on reduced bone health later in life. Optimal calcium intake is needed to achieve peak bone mass and to minimize bone loss during aging (Steelman and Zeitler, 2001).

Energy sources for the body include carbohydrates, protein, and fat. Carbohydrates and protein yield four kilocalories of energy per gram, while fat yields nine kilocalories per gram. The nine kilocalories of energy per gram make fat a richer source of energy when compared to 
carbohydrates and protein. Diets high in fat have been studied extensively to determine what, if any, effect they may have on various aspects of metabolism and bone composition. Several studies including a study conducted by Zipfel et al (2001) have found that anorexia nervosa patients that binge/purge are at an increased risk of developing osteoporosis. Sellmeyer et al (2001) found that elderly women with a high dietary ratio of animal to vegetable protein intake have more rapid bone loss and a greater risk of hip fracture than those with a low ratio. Sanderson et al (1997) found that under energy controlled conditions, a higher fat diet under a normal or higher total energy intake condition resulted in lower distal femur bone mineral content in mature male rats.

Energy is a limiting factor among those on energy restricting diets such as those with anorexia nervosa, Muslims fasting during the month of Ramadan, those fasting for political and other religious reasons. The goal of this research is to determine if energy supplementation has an effect on bone composition. The rationale for this study is that people on energy restricted diets may be at higher risk for reduced bone mineral composition which may result in an increase in fracture occurrence. 


\section{LITERATURE REVIEW}

\section{RESTRICTED ENERGY INTAKE CONDITIONS}

\section{Anorexia Nervosa}

Chronic illness, such as anorexia nervosa is a risk factor for the development of osteoporosis at a young age. Osteoporosis in anorexia nervosa can be caused by a variety of factors including malnutrition, amenorrhea and excessive exercise or a combination of these factors (Steelman and Zeitler, 2001). The mechanism of osteoporosis in anorexia nervosa is uncertain and probably multifactorial (Riggotti et al., 1991). Low bone mineral density in young adult women who have a history of long-term anorexia has been a persistent finding even if women attain a normal body mass index. This finding supports the concern that impairment of bone mineral accretion during adolescence may have long-term effects on bone health (Steelman and Zeitler, 2001).

Anorexia nervosa (AN) is an eating disorder that consists of a decrease in caloric intake, weight loss, amenorrhea, and behavioral changes (Riggotti et al., 1991). The restricted diet consumed by those with anorexia nervosa is usually low in fat and energy (Holman et al., 1995). Chronic anorexia nervosa is known to lead to osteopenia and osteoporosis in adults and is associated with a reduction in cortical bone mass (Riggotti et al., 1984; Riggotti et al., 1991).

A study conducted by Wong et al (2001) attempted to determine if bone mass is reduced in the early stages of anorexia nervosa in adolescents. This study evaluated the relationship between body weight, body mass index, and bone mineral content in these females. The study participants were twenty-four adolescent females aged eight to sixteen years having been diagnosed with anorexia nervosa based on criteria from the fourth edition of the Diagnostic and Statistical Manual of Mental Disorders (DSM-IV; American Psychiatric Association, 1994). 
Height and weight measurements were taken and body mass index (BMI) was calculated as well as bone density measurements performed by dual-energy X-ray aborptiometry. Bone density measurements were compared to controls available in a normative pediatric database. The results of this study do not indicate a significant relationship between body weight, BMI, or any clinically significant bone loss within the first twelve months of anorexia nervosa. These findings suggest that disease chronicity is important for the development of low bone mass (Wong et al., 2001).

Abrams et al (1993) conducted a study to determine if the bone demineralization in AN subjects was a result of a decrease in the rate of bone formation with subsequent bone resorption or due to inadequate calcium intake. Seven female subjects aged thirteen to twenty years participated in this study, which was performed after the participants were stabilized nutritionally. The results of the study indicated that calcium balance in the anorexia nervosa subjects was significantly lower due to increased urinary calcium excretion. Although the AN subjects had a higher intake of calcium, their true absorption of calcium was similar to that of control subjects, which suggests that the absorptive capacity of those with AN had decreased. This study determined that during the critical time of rapid bone formation during adolescence, abnormalities in mineral metabolism may lead to significant bone loss and may be a precursor to osteoporosis. The decreased bone calcium flow suggests that mineralized skeleton was formed slowly in subjects with AN and the decrease in their exchangeable calcium pool in bone indicates that subjects with AN had marked abnormality in bone formation and mineralization.

Zipfel et al (2001) conducted a study to determine the course of bone mineral density (BMD) and bone turnover in patients with $\mathrm{AN}$ and bulimia nervosa $(\mathrm{BN})$ across a $31 / 2$ year follow-up period. Bulimia nervosa is an eating disorder characterized by bingeing and purging 
behavior and is typically diagnosed in patients with a normal weight (DSM-IV; American Psychiatric Association, 1994). There were thirty-eight participants in this study with eating disorders and forty-two control participants. Body composition and BMD at the lumbar spine were measured by dual x-ray absorptiometry. Results of the study showed a high prevalence rate of osteopenia and osteoporosis at the lumbar spine for patients with AN at a mean duration of illness of three and seven years. Patients with the binge/purge subtype of AN were found to have the highest rate of bone resorption. Patients with BN did not show an elevated risk of osteoporosis.

A study by Beals and Manore (1998) was conducted to assess the energy and nutritional status of female athletes with subclinical eating disorders and to determine if these athletes were at greater risk for nutritional deficiencies than athletes who did not have eating disorders. The subjects were forty-eight female athletes between the ages of eighteen and thirty-six years from endurance and aesthetic sports. Twenty-four athletes had subclinical eating disorders and twenty-four athletes did not have eating disorders. Energy and nutrient intakes were determined by using weighed food records representing nutrient intake from food, including food supplements, only. Results of the study indicated that athletes with subclinical eating disorders had intakes of energy, protein, carbohydrate, and some micronutrients below recommended levels and significantly lower than intakes of control athletes. Micronutrient status was not affected negatively, which may be explained by vitamin/mineral supplement use. About half of the athletes with subclinical eating disorders failed to meet the recommended daily allowance for calcium and nine athletes were getting less than two thirds of the recommended daily allowance. Low calcium intakes, especially when combined with menstrual dysfunction, may contribute to 
decreased bone mineral density. More than half of the athletes with subclinical eating disorders in this study reported some form of menstrual dysfunction.

\section{RAMADAN FASTING}

Millions of Muslims all over the world fast during the month of Ramadan. Fasting in Islam is considered a controlled or partial type of fasting during which Muslims abstain from food and drink from dawn until sunset. Usually total food intake is limited during Ramadan fasting which may lead to reduced energy intake and weight loss (Sakr, 1975).

Several studies focusing on the effects of Ramadan fasting on body composition, body weight, and blood lipid levels have been conducted. One study by El Ati et al (1995) was conducted to determine effects of Ramadan fasting on anthropometric measurements in women. Researchers of this study found no effect from fasting on body weight or composition from the changes in feeding associated with Ramadan due to the possibility that metabolic changes may occur in order to preserve normal body weight and composition. Another study conducted by Sweileh et al (1992) found that Ramadan fasting resulted in significant weight loss, however, metabolism of those fasting slowed down in order to conserve energy stores. A study by Maislos et al (1993) after evaluating the effect of Ramadan fasting on plasma lipids, determined that there was no effect on total cholesterol or LDL-cholesterol. However, they did find that HDLcholesterol was significantly increased at the end of Ramadan fasting. A study by Hallak and Nomani (1988) found that Ramadan fasting did reduce body weight. In contrast to the study by Maislos et al (1993), Hallak and Nomani (1998) determined that there was a significant decrease in HDL-cholesterol and an increase in LDL-cholesterol with increased levels of saturated fat during the fasting period. These conflicting results indicate that further research is needed to determine the effect of prolonged fasting during Ramadan. 


\section{NITROGEN RETENTION}

Nomani et al (2000) studied the effect of an energy-restricted diet supplemented with coconut oil on nitrogen balance. The subjects of the study were thirty-six Wistar rats housed and cared for at the West Virginia University Laboratory Animal Facilities. The rats were weighed before feeding and randomly placed into individual stainless steel cages. The rats were fed a basal diet for the first four weeks of the experiment. The five experimental diets were fed to the rats for four weeks. The experimental diets consisted of the basal diet with varying levels of fat added. The added fats included coconut oil, corn oil, olive oil, cornstarch, and concentrated coconut oil. Total energy intake ranged from $67 \%$ to $75 \%$ of the requirement which means the experiment was conducted under a limiting energy environment. During the fourth week of the experiment, total feces and urine were collected daily for six days from each rat. Diet, feces, and urine were analyzed in duplicate for total nitrogen by the Kjeldahl method. After the rats were sacrificed, blood samples were collected by heart puncture and a clear serum sample was obtained after centrifuging. The serum was analyzed for total cholesterol and triglycerides by enzymatic methods. Fecal nitrogen was not affected by diet. Urinary nitrogen excretion was significantly higher in the basal group and nitrogen balance was positive but lowest in the basal group and highest in the experimental diet supplemented with $2 \mathrm{~g}$ of coconut oil. There were no differences among mean serum cholesterol levels for any of the diets which included low and high fat diets as well as low and highly saturated fats. The results of the study concluded that under energy-restricted conditions, a high-fat diet could serve as a source of energy and improve nitrogen balance without elevating blood cholesterol levels.

A study by Meluzzi et al (2001) was conducted to determine the nitrogen balance and the performance of laying hens fed diets with a protein content lower than the diets currently used in 
commercial practice but with adequate concentrations of amino acids. Ninety-six hens were divided into three groups of eight replicates and were fed diets formulated with three different protein concentrations (high, medium, and low) but the same energy content for sixteen weeks. In the first half of the trial, egg production and egg weight were similar in all three groups. From the ninth week onward in the study, the group receiving the medium concentration of protein laid heavier eggs and had slightly lower egg deposition and total mass. Nitrogen intake was related to the protein concentration of the diet. Food intake was almost the same between all three groups. Fecal nitrogen content decreased with reduction in dietary protein content and was about $50 \%$ of the intake. Based on the nitrogen fecal/intake ratio, the group receiving the medium concentration of protein showed better nitrogen utilization.

\section{BONE STRUCTURE AND FUNCTION}

Bone is the hard and extremely dense connective tissue that forms the skeleton of the body. It is composed of a matrix of collagen fibers. Cortical bone forms the outer shell of bone and consists of a hard, virtually solid mass made up of bony tissue arranged in concentric layers. Cancellous bone is the spongy bone found beneath the cortical bone and consists of a meshwork of bony bars with many interconnecting spaces containing marrow (Martin \& Guidos, 2000). The major functions of bone include support, locomotion, encasement of central nervous system tissue, and a reservoir for calcium, phosphate, and magnesium (Lee and Bennett, 2000). The proportions of cortical and cancellous bone differ at various sites in the skeleton. Cancellous bone is found mainly in the vertebrae and part of the hip while the midshaft, diaphyses, of the long bones consists entirely of cortical bone (Leonard and Zemel, 2002). The growing portion, metaphyses, located between the diaphyses and the epiphyses or end of the bone consist of relatively thin shells of cortical bone with large volumes of cancellous bone (Rockwood et al., 
1996). Cortical and cancellous bone do not respond to disease, drugs, mechanical loading (physical activity, activities of daily living), or aging in exactly the same way. Cortical bone fulfills mainly mechanical and protective functions while cancellous bone fulfills mainly a metabolic function (Leonard and Zemel, 2002). The distinguishing morphological feature of cancellous bone is its high level of porosity relative to cortical bone. This porosity leads to more

free surfaces and thus to more of the cellular constituents that inhabit those surfaces. As a result, cancellous bone is often more metabolically active and responsive to stimuli than cortical bone. This extends to the relationship between the internal structure and external mechanical loading, such as activities of daily living and exercise, of cancellous bone (Jacobs, 2000). The process through which bone mass is modified in the body is known to be influenced by both mechanical and metabolic stimuli (Hernandez et al., 2000).

\section{DIETARY FAT and BONE}

\section{Effect of Fatty Acids on Bone Formation}

Previous studies have shown that dietary lipids affect the fatty acid composition of membrane phospholipids and influence cell function. Lowering amounts of dietary fatty acids resulted in increased bone strength (Kokkinos et al., 1993). Watkins et al (2000) conducted a study to investigate how polyunsaturated fatty acids affect prostaglandin production and bone formation rate in rats. Sixty male weanling rats were randomly assigned to four groups and consumed ad libitum the basal diet with one of four fat treatments. The fat treatments were a mixture of safflower oil and menhaden oil at different ratios. Each dietary treatment contained $100 \mathrm{~g}$ of total fatty acids. Total fat concentration in each diet was $70 \mathrm{~g} / \mathrm{kg}$ of diet. After forty-two days of dietary treatment, the rats were sacrificed and tissue samples, including the right femur, right proximal tibia, and blood, were collected. Lipids in the diet and tissue samples were 
extracted with chloroform/methanol and cortical bone samples were cooled in liquid nitrogen and then pulverized to facilitate the extraction of lipids. Bone histomorphometric analysis was performed on the tibia and the results indicated a higher rate of bone formation in tibias of rats fed the greatest level of fatty acids. Results of this study showed that as the dietary ratio of polyunsaturated fatty acids declined, the concentration of total fatty acids declined in all lipids of the bone compartments studied. In addition, regression analysis suggested that bone concentrations of fatty acids were related to changes in prostaglandin production and may be associated with an altered rate of bone formation.

\section{EFFECT OF FAT SUPPLEMENTATION ON BONE FORMATION}

\section{Fat and Calcium Absorption}

Diets with high saturated fat content can produce deleterious effects on the absorption of dietary calcium and consequently have an adverse effect on bone mineralization in growing animals by interfering with intestinal calcium absorption. Therefore, dietary fat may have longterm consequences for skeletal health and related diseases such as osteoporosis (Wohl et al., 1998).

A study by Wohl et al (1998) examined the effects of a high-fat diet on mature bone structure and mechanics without energy restriction. A total of thirty, mature roosters were used for this study. Whol et al (1998) hypothesized that a high-fat diet would reduce mineral content in mature bone, and would result in a bone with less strength than bone exposed to a low-fat diet. The influence of the high and low-fat diets on weight-bearing cortical and cancellous bones was specifically investigated. The roosters were randomly placed into one of three groups: control, high fat, and low fat, with all the diets having the same total energy level. The high fat diet was rich in saturated fats ( $8 \%$ palmitic acid). The content of the high fat diet was $95.1 \%$ pure tri- 
palmitate. In the low fat diet, fatty acids were substituted by alpha floc cellulose. The roosters were fed the diets for twenty weeks. Bone mineral content was determined by ashing cancellous bone samples taken from the femur and the tibia. Bone mineral content was also determined for cortical and cancellous bone samples by cross-sectional area measures for morphometry. Cortical bone mechanical testing was performed on the tarsometatarsus. At the end of the study period, the roosters on the high fat diet had a significantly higher body mass than the roosters fed the control diet. The results of the study showed there were no significant high fat diet effects on mature cortical bone mechanical properties, structure, or mineral content. Diet did affect cancellous bone composition. Roosters that were fed the low fat diet had cancellous bone mineral content that was significantly greater than roosters fed the high fat diet. Additionally, low fat cancellous bone strength was consistently greater than high fat. The results of this study also indicate that adult cortical bone was not as sensitive to a high fat diet as are growing animals as demonstrated by Atteh and Leeson (1984). The potential for adverse effects of a high fat diet on intestinal calcium absorption in the mature animal may be more apparent in cancellous bone, with its faster rate of turnover, than in cortical bone.

\section{ENERGY RESTRICTION, BONE DENSITY, and BONE STRENGTH}

\section{Energy Restriction and Bone Density}

A study by Talbott et al (2001) was conducted to determine the influence of energy restriction on bone density and biomechanical properties in mature and aged female rats. Twenty-seven rats from two age groups of female rats were examined in this study, with agematched controls included in both groups. The rats were twenty weeks old (mature), and fortyeight weeks old (aged) at the beginning of the study. The energy restricted diet contained $40 \%$ less energy than the control diet, accomplished by reducing the carbohydrate content and feeding 
a reduced quantity. Daily intakes of protein, fat, fiber, vitamins, and other minerals were the same in each energy group. After the nine week experimental period, the rats were sacrificed and bone samples collected for analysis. Bone composition testing was performed on the right tibia after ashing the bone by measuring calcium content using atomic absorption spectrophotometry. Biomechanical testing was performed on the left femur by three-point bending and right humerus by torsion testing. Bone density was determined by radiography of the right tibia, humerus, and femur. Values of bone density were expressed as a percentage of the bone density of rats consuming food ad libitum. Results of the study indicated that bone densities of the femur, humerus, and tibia were greater in aged than in mature rats. In energy restricted rats, femur density was less than that of controls in both age groups, and in aged rats, energy restriction also reduced bone density of the humerus and tibia. Biomechanical properties exhibited age and energy related effects. Femurs of aged rats had higher peak load and bending stiffness than mature rats. Aged, energy restricted rats had lower femur peak load bending stiffness and humerus peak torque than controls. Bone density of the femur and humerus were positively correlated with calcium content of the bones. A previous study conducted by Talbott et al (1998) showed that energy restriction elevates bone resorption and decreases whole body bone mineral density in aged but not growing rats. This study extends the previous data by showing reduced bone density at three sites and reduced biomechanical properties in aged rats. The regression analysis performed in this study suggests there is a direct relationship between bone density and bone strength, which may be reduced by energy restriction. This implies that adequate energy intake and maintenance of body weight are important factors in determining bone strength in aged rats. 
In a controlled trial, Ricci et al (2001) attempted to determine if bone turnover markers and bone-regulating hormones can explain changes in BMD due to weight loss in obese postmenopausal women during moderate energy restriction. Twenty-seven women were participants in the study, fourteen were in a weight loss group and thirteen were in a weight maintenance group. Total urinary pyridinium cross-links were measured as well as urinary calcium. Total-body BMD and bone mineral content were measured by dual-energy X-ray absorptiometry before and after weight loss. Total body BMD decreased in the weight loss group more than in the weight maintenance group. Total-body bone mineral content did not change significantly with either group. Results of this study also indicated that markers of bone resorption increased during energy restriction. Pyridinium cross-links increased significantly with energy restriction after one week and remained elevated for the duration of the study. The decline in BMD after weight loss was due to negative bone balance secondary to an increase in bone resorption relative to formation. Energy restriction appears to result in an elevation in bone resorption which reduces bone mineral density.

A study by Nomani et al (2002 $2_{\mathrm{a}}$ ) estimated nitrogen balance, mineral composition, and fracture load of the neck of the femoral proximal head on thirty growing Wistar strain rats after eight weeks of study period. The femoral heads of the rats were broken by a Servo Hydraulic Testing Machine. During the study period, the rats were fed a semi-purified diet supplemented with various kinds of fat including, coconut, olive, and corn oils, and starch. The energy intake of the rats ranged from 67-77 percent of the requirement for growing rats. Regression approach was used to analyze the data. Results of the study showed that with supplementation of energy, nitrogen balance improved significantly due to reduced urinary nitrogen excretion. Also, the fracture load of the femoral head was positively associated with the mineral composition. In 
addition, the results showed significant negative associations of mineral concentrations in the femoral heads with nitrogen excretion suggesting that energy supplementation under restricted energy intake conditions may result in higher mineral concentration and better protein matrix in the spongy bone. The higher mineral concentration and better protein matrix in the bone consequently results in higher femoral head fracture load.

\section{Dietary Fat and Mineral Metabolism}

Two experiments were conducted by Atteh et al (1983) to determine the effect of levels and sources of fat on performance and mineral metabolism of boiler chicks. The first experiment used one hundred and ninety-two day-old male broiler chicks fed four experimental diets ad libitum to six replicate cages containing eight chicks each. The four experimental diets were similar in levels of protein, energy, and minerals. The treatments consisted of increasing levels of animal-vegetable fat substituted for corn starch as a source of energy. The trial period lasted three weeks after which two chicks per replicate were randomly selected, had blood drawn, and were subsequently killed. The left tibia of each of the killed chicks was cleaned, dried and ashed. The ashed samples were analyzed by atomic absorption spectrophotometry for calcium, magnesium, manganese, and zinc content. The results of the analysis of the ashed samples from this first experiment indicated that fat supplementation, regardless of the amount, resulted in significantly reduced bone calcium content. This effect was not shown for the other minerals. The second experiment used three hundred and eighty-four day old male broiler chicks that were fed twelve experimental diets consisting of a $3 \times 2 \times 2$ factorial combination of fat source, dietary calcium, and vitamin $\mathrm{D}_{3}$. The source of supplemental fat was animal-vegetable blend or corn oil, each supplying $5 \%$ of the diet. Calcium content of the diet was increased from .9 to $1.2 \%$ and Vitamin $\mathrm{D}_{3}$ content of the diet was increased from 1600 to $3200 \mathrm{IU} / \mathrm{kg}$. Each of the diets was 
tested with four replicate cages of eight chicks each with the diet supplied ad libitum for three weeks. After the first 10 days, a mineral retention study was conducted with these same chicks. Excreta were collected over 48 hours, dried, and then ashed. During the third week of the experiment, leg deformities were subjectively evaluated. At the end of the trial, two chicks per replicate were randomly selected for blood and bone sampling as described above in the first experiment. Ash from the excreta and bone samples was treated as described in the first experiment, as well. The results of the second experiment indicated that there was a tendency for the source of fat (corn oil and A-V blend) to increase the incidence of leg deformities and increasing the calcium or vitamin $\mathrm{D}_{3}$ content of the diets tended to reduce this problem, though these effects were not significant. The results also showed there was no significant difference in calcium retention between the two sources of fat, however, addition of either significantly reduced calcium retention. In addition, increases in calcium or vitamin $\mathrm{D}_{3}$ content had no significant effect on calcium retention. Magnesium retention did not differ for the two sources of fat, but corn oil significantly reduced magnesium retention relative to diets without fat. There was no significant effect of the diet treatments on phosphorus, manganese, or zinc. In both experiments, the addition of supplemental fat to the diet improved the rate of growth of chicks and increased their body weight. Both experiments showed that the addition of fat to the diets resulted in a decrease in the rate of bone calcification and a significant reduction in bone calcium and magnesium content. The increase in leg deformities in experiment 2 could be a result of a synergistic effect related to reduced bone calcification and to the effect of increased body weight on the skeletal structure. 


\section{Fat and Bone Strength}

Sanderson et al (1997) studied the effects of fat intake on femoral bone mineral content in mature male rats. However, Sanderson et al (1997) added the parameter of calorie restriction based on each rat's own baseline consumption. The study used two hundred fifty six male rats housed in individual cages and randomly assigned to one of four experimental diet groups. Diets A and B were fed in amounts to achieve a "normal" caloric intake (20\% less calories than ad libitum for groups A and B). Diets C and D were approximately $40 \%$ less calories than ad libitum for groups $\mathrm{C}$ and $\mathrm{D}$. The initial caloric restriction began when the rats were seventeen months old, with further restriction at nineteen months of age. Groups A and B were further restricted to $35 \%$ less than ad libitum and groups $\mathrm{C}$ and $\mathrm{D}$ were $50 \%$ less than ad libitum intake. To avoid malnutrition, diets for groups $\mathrm{C}$ and $\mathrm{D}$ were enriched relative to diets $\mathrm{A}$ and $\mathrm{B}$ in content of protein, vitamins, and minerals to provide nearly equal weekly intakes of these substances for all rats. Fat provided $10,33,35$, and $50 \%$ of the caloric intake from the diets, respectively. The results of the study indicated that adult-onset calorie restriction had no direct effect on femoral bone mineral content but the highest fat intake in group D animals did result in lower femoral bone mineral content. The results of these two studies, while having similar findings, suggest further investigation into the potential adverse skeletal effects of high fat diets under ad libitum and restricted energy intake conditions.

\section{EFFECT OF DIETARY PROTEIN ON BONE COMPOSITION}

There are other factors that may affect calcium metabolism and bone composition including a high protein intake. Excess dietary protein can adversely affect bone due to the effect on acid-base metabolism which affects urinary calcium and ultimately bone. Bone is a large ion exchange buffer system. Bone responds to acid with the rapid release of carbonate, citrate, and 
sodium. A diet consistently high in protein from animal sources, causes bone and calcium to be mobilized as a buffer against the acid from the metabolism of protein (Barzel and Massey, 1998).

\section{Bone Turnover Rate at Different Levels of Dietary Protein Intake}

Kerstetter et al (1999) conducted a study to determine the effect of dietary protein on markers of bone turnover in sixteen, healthy young women with a low, medium, and high level of protein intake. The study protocol included three cycles, each of which consisted of a two week adjustment diet followed by four days of experimental diet and three days of ad libitum diet. The experimental diet was controlled in calcium, sodium, and phosphorus, and contained one of three levels of dietary protein: low, medium, or high. During the two week adjustment period, subjects were instructed to self-select their diets to contain approximately one gram of protein per kilogram of body weight. During the four day experimental period, low protein intake was $.7 \mathrm{~g} / \mathrm{kg}$, medium was $1 \mathrm{~g} / \mathrm{kg}$, and high was $2.1 \mathrm{~g} / \mathrm{kg}$. Results of the study indicated urinary calcium was significantly decreased during the low protein diet compared to the medium protein diet and was significantly increased during the high protein diet compared to the medium protein diet. Dietary protein may exert a variety of effects on skeletal homeostasis involving both intestine and bone. Current data suggests that at high levels of dietary protein intake, urinary calcium excretion is elevated despite normal intestinal calcium absorption. Also, high levels of dietary protein are associated with increased rates of bone resorption.

\section{Effect of High Ratio of Animal to Vegetable Protein on Bone Loss}

The study by Sellmeyer et al (2001) was conducted to determine if a diet with a high ratio of animal to vegetable foods increases the rate of bone loss and the risk of fracture. Data obtained from a prospective cohort study of 1035 white women aged greater than sixty-five years were collected and the protein content of ingested food was used to quantify the ratio of animal 
to vegetable foods. Dietary intake was determined using a food-frequency questionnaire. Bone mineral density measurements were obtained for 742 women at the beginning of the study and during the follow up three and a half years later. Women with a high ratio of animal to vegetable protein intake (48g animal protein and $11 \mathrm{~g}$ vegetable protein per day in the high group and $23 \mathrm{~g}$ animal protein and $19 \mathrm{~g}$ vegetable protein per day in the low group) had a significantly higher rate of femoral neck loss than those with a low ratio. Risk of hip fracture was also significantly higher in women with a high ratio of animal to vegetable protein intake as compared to those with a low ratio. In this cohort of older women, the rate of bone loss was higher in women with high ratios of animal to vegetable protein intake. This may be a result of the detrimental effects on bone of an imbalance between dietary acid and base balance, which may become more important with age due to decreases in renal function and the ability to excrete dietary acid loads. The researchers of this study acknowledged that bone loss and risk of hip fracture are multifactorial and the association between a high ratio of dietary animal to vegetable protein intake and a higher rate of bone loss and hip fracture may be due to a risk factor not measured.

\section{Dietary Protein Intake and Bone Mass}

The relationship between diet and other factors that impact bone density is unclear (Cooper et al., 1996). Cooper et al (1996) conducted a study to examine the relationship between the consumption of calcium, phosphorus, vitamin D, protein, fat, and total energy and bone density using data from a cross-sectional population-based study performed in the northern United States. Two-hundred ninety women older than thirty years were participants in the study of which, seventy-two were pre-menopausal and two-hundred eighteen were post-menopausal. Consumption of the above mentioned nutrients was estimated from a 7-day dietary record and participants had bone mineral densities determined by dual photon absorptiometry for the lumbar 
spine and right femur (proximal and proximal shaft). Bone mineral content was measured at the mid and distal radius of the nondominant arm with single photon absorptiometry. After collecting serum and urine specimens from the participants, the specimens were analyzed for serum and urine calcium by atomic absorption spectrophotometry. Serum phosphorus was determined by routine automated methods. Based on the data collected from the 7-day dietary record, median daily energy consumption was $1704 \mathrm{kcal}$; the median intake of protein was $72 \mathrm{~g}$ and fat was $74 \mathrm{~g}$. Median dietary calcium intake was $863 \mathrm{mg}$ daily and did not differ significantly between the pre- and post-menopausal women. The 7-day dietary record only provides information about consumption at one particular point in time and caution is required in making generalizations about the data results. The results of this study showed that for the premenopausal women there was a positive association between done density and intakes of protein, calcium, and phosphorus. The association with protein was strongest at the distal radius and femoral shaft and attained significance at the femoral neck and midradius. Bone mineral was also significantly associated with dietary intake of phosphorus at four skeletal sites, including the distal radius, and with calcium intake at the distal radius. For the post-menopausal group of women, there were only significant findings for one nutrient. There was a negative association between fat consumption and bone mineral at the lumbar spine and distal radius. In this study, there were significant associations found between the intakes of protein and those of calcium and phosphorus among pre-menopausal women, however, these relationships were not as evident among the post-menopausal women, suggesting further research is needed to determine the influence of dietary factors, especially protein, on bone mass. 


\section{Effect of Dietary Protein on Bone Loss in Elderly Men}

A study by Hannan et al (2000) was conducted to examine the association between baseline dietary protein and a subsequent four-year change in the skeletal health of elderly men and women from the population-based Framingham Osteoporosis Study. This study also evaluated the effect of animal and nonanimal protein intake for a possible effect on bone loss in older individuals. A total of 855 cohort members participated in the baseline study in which they had femoral BMD measurements and proximal radial scans and completed a semiquantitative Food Frequency Questionnaire (FFQ). As part of their regular clinic visit four years later, 615 subjects who had baseline BMD measurements and the FFQ assessed, had repeat BMD measures. Dietary protein intake was expressed as percent of energy from protein. Components of protein were divided into animal and nonanimal protein intake and expressed as percent of energy from animal protein and percent of energy from nonanimal protein. Protein comprised approximately $16 \%$ of total energy intake. Approximately $10 \%$ of energy intake was from animal protein. Results of the study showed that a lower percent protein intake was significantly related to greater BMD loss at femur sites, but not at radial sites. Similar to the overall protein effect, a lower percent of energy intake from animal protein was also significantly related to bone loss at femoral BMD sites. The participants had a mean protein intake of $68 \mathrm{~g} /$ day and percent protein of $16 \%$ which is similar to the recommendations for total protein and percent of energy from protein set by the U.S. Government. As stated previously, in this study, lower protein and lower animal protein intake were related to greater BMD loss at femur sites. Elders with a higher protein intake had reduced bone loss which suggests that protein intake is important in maintaining bone or minimizing bone loss in elderly persons. The long-term influences of protein intake and its possible acid load on bone health are unclear. The results of 
the study by Hannan et al (2000) suggest that normal protein intake (intake within the RDA) is associated with maintenance of BMD. The results of the previous three studies suggest that further research is needed in order to determine the exact role of protein in bone health.

\section{MINERAL SUPPLEMENTATION AND EFFECT ON BONE STRENGTH}

\section{Minerals and Bone Strength}

A study conducted by Ruff and Hughes (1985) was performed to determine the effect of supplementation of calcium, phosphorus, and manganese on the bone strength of the humerus in broiler chicks. Ruff and Hughes (1985) used three experiments using different diets. All three experiments were equicaloric and isonitrogenous. Experiment one consisted of increasing calcium $(\mathrm{Ca})$ and phosphorus $(\mathrm{P})$ levels while maintaining a constant $\mathrm{Ca}: \mathrm{P}$ ratio. The second experiment maintained a constant $\mathrm{Ca}$ level while increasing $\mathrm{P}$ levels. The third experiment increased both $\mathrm{Ca}$ and $\mathrm{P}$ levels as well as increasing levels of manganese (Mn) while holding a constant $\mathrm{Ca}: \mathrm{P}$ ratio. The chicks were one day old at the beginning of the study and grown to seven weeks of age. The left humerus was removed from the birds for fracture load testing in all three experiments. The bones were broken to $100 \%$ fail with force applied to break the bones into two pieces. Ash samples were used to determine $\mathrm{Ca}, \mathrm{Mn}$, and $\mathrm{P}$ percent by atomic absorption spectrophotometry. Results of the experiments showed that the humerus peak load values were significantly greater for those fed the diet with the highest levels of $\mathrm{Ca}$ and $\mathrm{P}$ in the first experiment than those fed intermediate levels. The humerus break load and peak load were greatest for the birds fed 0.70 and $0.90 \%$ phosphorus as compared to 0.50 or $1.10 \%$ in the second experiment. In the third experiment with $\mathrm{Mn}$ incorporated into the diet, there was no significant effect of this mineral on humerus strength. 


\section{Hypotheses}

In an earlier report related to this study, energy supplementation reduced urinary excretion and improved nitrogen balance (Nomani et al., 2000). In the present study, the null hypotheses are:

1. Urinary nitrogen excretion is not associated with bone mineral composition of the shaft of the tibia

2. Higher bone mineral composition (calcium, magnesium, phosphorus) is not associated with breaking load of the midshaft of the tibia

3. Bone mineral composition does not affect bone stiffness

\section{Hypothesis Model}

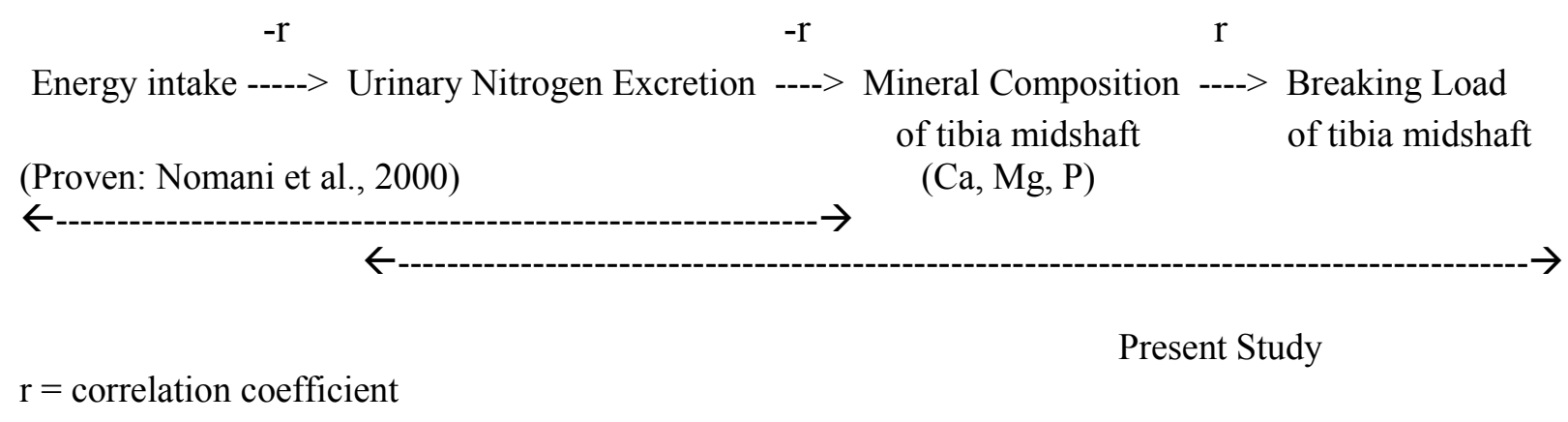




\section{METHODOLOGY}

This study was conducted on thirty-six weanling male albino Wistar strain rats that were obtained from Hilltop Laboratory Animals Inc., Scottdale, PA, USA. The rats used for this study were the same animals that were used in two previous, related experiments. The rats were housed and cared for at the West Virginia University Laboratory Animal Facilities. The rats were weighed before feeding and randomly placed into individual stainless-steel cages. All experimental procedures were approved by the Institutional Animal Care and Use Committee. The ingredients for the experimental diets were obtained from ICN Pharmaceuticals Inc., Costa Mesa, CA, USA, and a modified form of AIN-76 formula for rat by The American Institute of Nutrition, (AIN, 1977), was used to prepare the basal diet (Nomani et al., 2000). This research was supported in part by W.V.U. Senate Research Grant and the W.V. Agriculture and Forestry Experimental Station, Project No. 888, and approved by the Director of W.V. Agr. \& For. Expt'1 Stn. As Scientific Article No. 2731.

\section{Experimental Diets}

The basal diet (Table 1) consisted of $15.0 \%$ casein supplemented with $0.3 \%$ DLmethionine, $66.8 \%$ cornstarch, $10.0 \%$ corn oil, $0.2 \%$ cholesterol, $0.2 \%$ choline bitartrate, $1.0 \%$ vitamin mix, 3.5\% mineral mix, and 3.0\% alphacel (cellulose). The basal diet was given to all the rats during the pre-experimental phase, which was the first four weeks following their arrival at the animal care facility. The rats were fed in a controlled manner (Table 2 ) in order to create a restricted energy intake condition (67\%-75\% of the requirement) during the following four weeks of the experimental phase (Nomani et al., 2000). The basal diet was used to create the five experimental diets (Table 3): Diet 1 (Basal), Diet 2 (Basal $+1 \mathrm{~g}$ of coconut oil), Diet 3 (Basal + 
$1 \mathrm{~g}$ of olive oil), Diet 4 (Basal $+1 \mathrm{~g}$ of corn oil), Diet 5 (Basal $+2.25 \mathrm{~g}$ of corn starch), and Diet 6 (Basal $+2 \mathrm{~g}$ of coconut oil). All 6 diets had the same amount of nitrogen, minerals, fiber, and cholesterol. The rats were randomly divided into six groups with six rats in each group. Each rat was placed in an individual cage and fed one of six diets for the next four weeks. During the fourth week of the experiment, total feces and urine were collected daily for six days from each rat. Diet, feces, and urine were analyzed in duplicate for total nitrogen by the Kjeldahl method. Following completion of the collection of data, the rats were sacrificed by an injection of sodium barbital and then placed in individual plastic bags. The rats were labeled by group A-F and also by number 1-6. The rats were placed in plastic storage containers that held six rats each, and then frozen in the Animal Research Laboratory in the Agricultural Sciences Building. Once frozen, the rats were removed from the Animal Research Laboratory and placed in the freezer in the Advanced Nutrition Laboratory in the Agricultural Sciences Building (Nomani et al., 2000). 
TABLE 1

COMPOSITION OF BASAL DIET

\begin{tabular}{|l|c|c|}
\hline $\begin{array}{c}\text { Diet } \\
\text { Constituent }\end{array}$ & $\begin{array}{c}\text { Amount, } \\
\text { percent by weight }\end{array}$ & $\begin{array}{c}\text { Amount in 14 grams of } \\
\text { diet, g }\end{array}$ \\
\hline Casein & 15.0 & 2.100 \\
\hline DL Methionine & 0.3 & 0.042 \\
\hline Vitamin Mixture & 1.0 & 0.140 \\
\hline Mineral Mixture & 3.5 & 0.490 \\
\hline Alphacell (Cellulose) & 3.0 & 0.420 \\
\hline Corn Oil & 10.0 & 1.400 \\
\hline Cholesterol & 0.2 & 0.028 \\
\hline Choline Bitartrate & 0.2 & 0.028 \\
\hline Corn Starch & 66.8 & 9.352 \\
\hline \multicolumn{1}{|c|}{ TOTAL } & 100 & 14 \\
\hline
\end{tabular}


TABLE 2

QUANTITIES OF EXPERIMENTAL DIETS PROVIDED

\begin{tabular}{|l|l|l|l|l|l|}
\hline & Wk. 1 & Wk. 2 & Wk. 3 & Wk. 4 & $\begin{array}{c}\text { Wk. 5 - Wk. 8 } \\
\text { Experimental Diet } \\
\text { (g/day) }\end{array}$ \\
\hline $\begin{array}{c}\text { All Animals Fed: } \\
\text { Basal Diet (g/day) }\end{array}$ & 10.00 & 11.00 & 12.00 & 13.00 & \\
\hline Diet 1: Basal (B) & & & & & 14.00 \\
\hline Diet 2: B+Coconut oil & & & & & 15.00 \\
\hline Diet 3: B+Olive oil & & & & & 15.00 \\
\hline Diet 4: B+Corn oil & & & & & 15.00 \\
\hline Diet 5: B+Starch & & & & & 16.25 \\
\hline $\begin{array}{c}\text { Diet 6: B+High } \\
\text { Coconut oil }\end{array}$ & & & & & 16.00 \\
\hline
\end{tabular}

Constituents were from the same source as those in Table 1. 
TABLE 3

COMPOSITION OF EXPERIMENTAL DIETS

\begin{tabular}{|l|c|c|c|c|c|c|}
\hline Constituents (g) & $\begin{array}{c}\text { Diet 1 } \\
\text { Basal (B) }\end{array}$ & $\begin{array}{c}\text { Diet 2 } \\
\text { B+Coconut oil }\end{array}$ & $\begin{array}{c}\text { Diet 3 } \\
\text { B+Olive } \\
\text { oil }\end{array}$ & $\begin{array}{c}\text { Diet 4 } \\
\text { B+Corn oil }\end{array}$ & $\begin{array}{c}\text { Diet 5 } \\
\text { B+Starch }\end{array}$ & $\begin{array}{c}\text { Diet 6 } \\
\text { B+High } \\
\text { Coconut oil }\end{array}$ \\
\hline Basal Diet & 14.00 & 14.00 & 14.00 & 14.00 & 14.00 & 14.00 \\
\hline Coconut oil & -- & 1.00 & -- & -- & -- & -- \\
\hline Olive oil & -- & -- & 1.00 & -- & -- & -- \\
\hline Corn oil & -- & -- & -- & 1.00 & -- & -- \\
\hline Corn starch & -- & -- & -- & -- & 2.25 & -- \\
\hline Coconut oil & -- & -- & -- & -- & -- & 2.00 \\
\hline TOTAL (g/d) & 14.00 & 15.00 & 15.00 & 15.00 & 16.25 & 16.00 \\
\hline
\end{tabular}

Constituents were from the same source as those in Table 2. 


\section{Dissection of the femur}

In preparation for dissection, the rats were removed from the Advanced Nutrition Lab and taken to the Animal Facilities Laboratory at the Health Sciences Center. The rats were then thawed in the refrigerator for eighteen hours at $44^{\circ} \mathrm{F}$. The rats were then removed and taken to the necroscopy room at the Musculoskeletal Research Center to be dissected. For this, the second related experiment, the left femur was removed, cleaned, and then stored. The femurs were placed in individual plastic bags and numbered by group and rat number. The remainder of the rat was placed in a new plastic bag and numbered with the original group and rat number. The rats were then placed in the original plastic containers and returned to the freezer of the Animal Facilities Laboratory at the Health Sciences Center. The left femurs of thirty of the thirty-six rats (Groups A-E) were then used to determine bone density, fracture load testing, and bone mineral composition (Nomani et al., 2002 a).

\section{PRESENT STUDY}

\section{Tibia and Forelimb Dissection and Cleaning}

The rat tibia of thirty of the thirty-six rats, (Groups A-E), was used to determine fracture load and bone mineral composition. Only thirty rats were used due to freezer failure and one group of six rats was not held at freezing and therefore was not usable. The rats were taken out of the freezer and allowed to thaw for about five minutes prior to the final dissection stage. The final dissection stage involved the removal of the left tibia and left and right forelimbs from the thirty rats. The rats were dissected using \#10 and \#15 surgical blades. The left tibia was removed by cutting the connective tissue that remained from the prior removal of the femur. Following the removal of the left tibia, the left and right forelimbs were removed from each rat. The forelimbs were also removed using \#10 and \#15 surgical blades. The incision was made just 
around the scapula of each limb and then followed the shape of the limb cutting the connective tissue between the limb and the body of the rat to remove it. Immediately following the removal of each limb, the limbs were placed into a plastic bag labeled with the rat group and number they belonged to. After the removal of all three limbs, the rats were disposed of properly. Each set of limbs was placed in a larger plastic bag and stored in plastic containers and placed in the freezer at the Human Nutrition Laboratory at the Agricultural Sciences Building. The bones were moved to the Musculoskeletal Research Center for cleaning. Only the left tibia was used for this part of the study. The hindlimbs were removed from the freezer and allowed to thaw for five minutes. The tibia was cleaned using \#10 and \#15 surgical blades to remove the hair, skin, and muscle covering the bone. The fibula was removed using a surgical blade or surgical scissors. The left and right humerus bones of the forelimbs were also cleaned in the same way. Normal saline solution ( $0.9 \%$ sodium chloride) was used to help clean and dissolve the remaining tissue from the bone. Then the cleaned bone was thoroughly doused with the saline to prevent dehydration, wrapped in gauze, and placed in a plastic bag labeled with the rat group and number. The bone was refrozen until the data were collected. When ready to collect the data, the bones were thawed for about five minutes, removed from the plastic bags, and examined for any remaining tissue to determine if further cleaning was required.

\section{BONE PHYSICAL PROPERTIES}

\section{Length and Diameter}

Length of the each bone was measured three times using a Mitutoyo series 500 digital caliper (101 East Gloucester Pike, Barrington, NJ) in millimeters. The three measurements were averaged to obtain the length of the bone. The diameter of each tibia was measured in millimeters using the above mentioned digital caliper. The diameter was measured at three 
different points on the tibia, the proximal end (Figure 1), the distal end (Figure 2), and the midshaft end (Figure 3) at the mediolateral and anterior-posterior direction. The proximal end was measured across the widest area of the bone at the proximal end. The mid-shaft diameter was determined by using the average length of each tibia and then dividing by two to obtain the mid-shaft of the bone. The mid-shaft diameter was then measured at this point. The distal end was measured across the widest area of the bone at the distal end. Three measurements were taken at each of these points and then averaged to obtain the proximal end, midshaft, and distal end diameters. The bones were once again doused with saline, wrapped in gauze, and placed in plastic bags and frozen until fracture load testing was performed.

Figure 1. Proximal End Diameter Diameter (Medial-lateral)

Proximal End

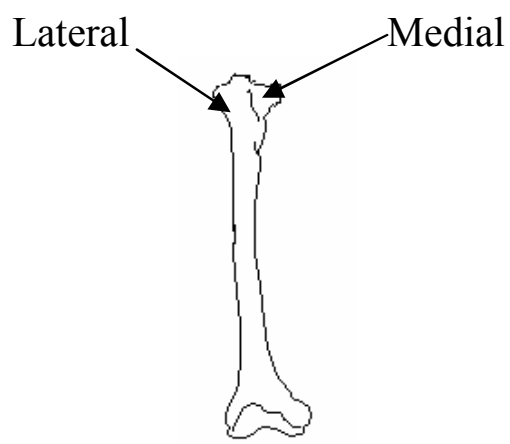

Figure 2. Distal End Diameter

Diameter (Medial-lateral)

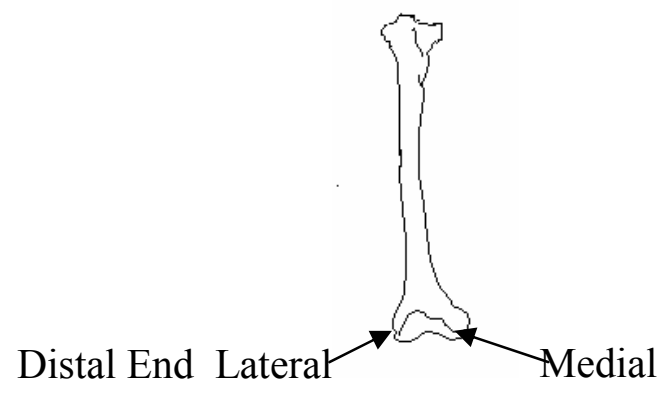

Diameter (Anterior-posterior)

Proximal End

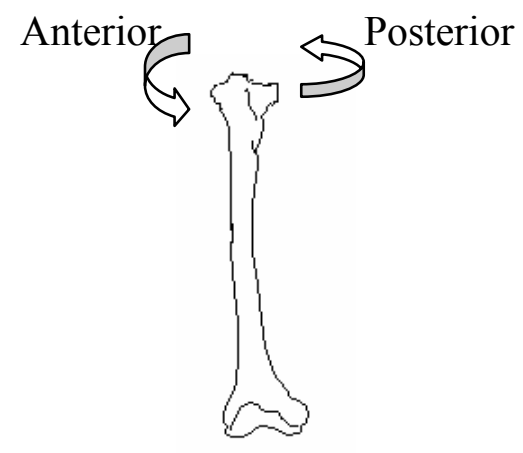

Diameter (Anterior-posterior)

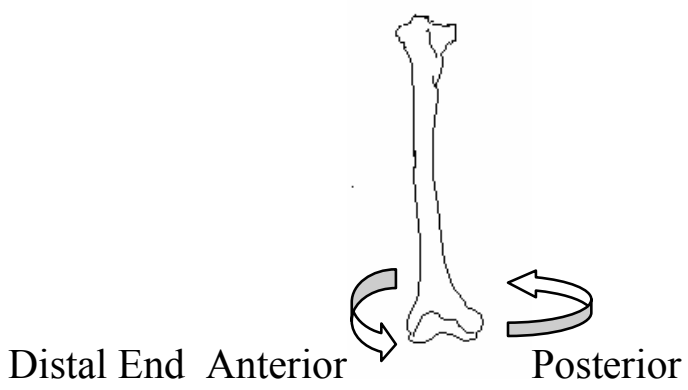


Figure 3. Midshaft Diameter
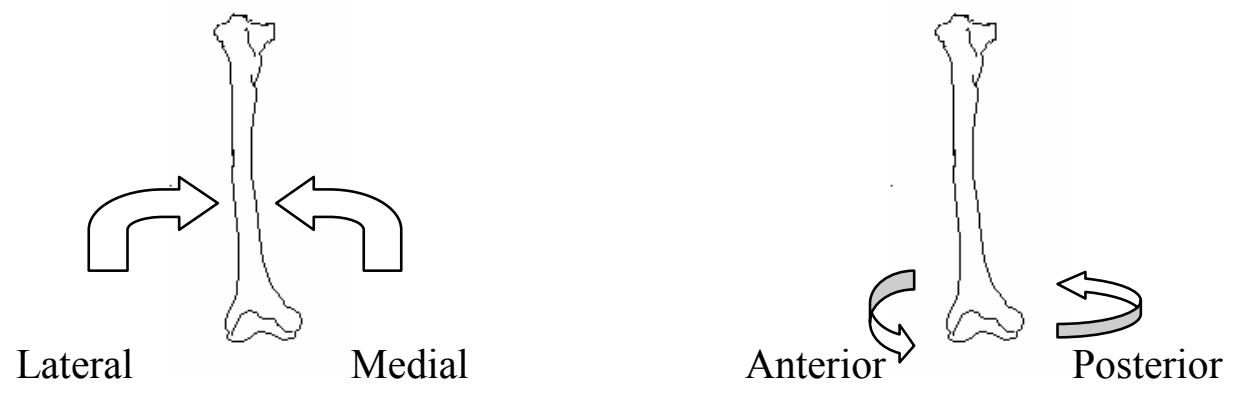

\section{Weight of Whole Bone and Parts of Bone}

At the time of fracture load testing, the bones were removed from the freezer and allowed to thaw for about five minutes and examined for excess tissue remaining. Any remaining part of the fibula was removed using a small, electric, circular saw with a 1" diameter, slitting blade (Dremel Moto-Tool Model 380-5, Racine, WI). Once completely free of tissue, each whole bone was weighed using a Model A-160 analytical balance scale (Denver Instrument Company, USA). Measurements were taken three times for each bone and then averaged to determine the weight of the bone. After weighing the whole bone, the proximal end was cut off at the insertion point of the patellar tendon using the above mentioned saw. Once severed, the proximal end was weighed three times on the same balance used previously, the weights were averaged, and then the ends were doused with saline, wrapped in gauze, and stored in a labeled plastic bag. The distal end was then cut $5 \mathrm{~mm}$ from the end of the bone using the same saw, weighed in the same manner as the proximal end, and stored in the same way. The three weights were averaged as well. The remainder of the bone (midshaft) was measured using digital calipers to find the midpoint. The bone was measured from the point at which the fibula was attached to the 
proximal end severed. The measurement was divided by two to obtain the midpoint of the bone to determine the point of load placement. The mid-shaft was then weighed three times and the weights averaged to obtain the weight of the mid-shaft of the bone.

\section{Volume of Midshaft}

The volume $\left(\mathrm{mm}^{3}\right)$ of the midshaft was estimated by the following method:

Medial-lateral diameter, $\mathrm{mm}+$ Anterior-posterior diameter, $\mathrm{mm} / 2$ = Mean Diameter, $\mathrm{mm}$

Mean Diameter $/ 2$ = Radius, $\mathrm{mm}$

Volume $=\Pi \mathrm{r}^{2} \mathrm{x}$ Length, $\mathrm{mm}=\mathrm{mm}^{3}$

Density $=\frac{\text { Dry matter in } \mathrm{mg} \text { of shaft }}{\text { Volume of shaft, } \mathrm{mm}^{3}}$

Density $=\frac{\mathrm{wt}}{\text { Volume }}$

\section{Fracture Load Testing}

After weighing, the midshaft bones were rehydrated in a normal saline solution for ten minutes. After ten minutes, each bone was removed and the three point bend test, (Figure 4), was performed to determine the breaking load and stiffness (displacement), (Figure 5), of the bones using a Material Testing System (MTS) to fracture the bone (MTS Systems Corporation, Minneapolis, MN). The MTS machine was 5 kips controlled with a 445 controller. A Zenith Data Systems Computer, (USA), was used for data acquisition using Labtech Notebook software, version 7.3 (Wilmington, MA). The data acquisition board was a Dash 16 (Metrabyte Corp., Stoughton,MA). The bone was positioned resting on the medial side touching the two fixed rollers on the MTS. Load was applied through the medial aspect with an indenter with roller end at $0.2 \mathrm{~mm} / \mathrm{sec}$. to the midpoint of the bone until fracture. The constant unsupported length at the time of fracture was $15 \mathrm{~mm}$. The bones were soaked in saline, wrapped in gauze, 
labeled and stored in plastic bags and frozen after breaking. The samples were taken to the Animal Nutrition Lab in the Agricultural Sciences Building in order for dry weight and bone mineral content analysis to be conducted.

Figure 4. Three-point break

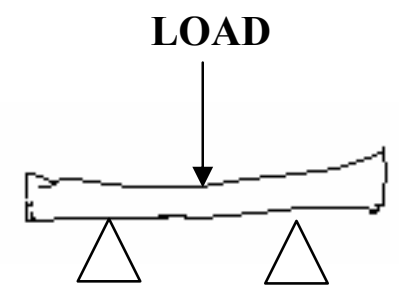

Figure 5. Displacement

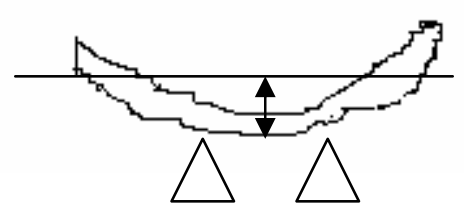

\section{Dry Matter Measurement}

In the Animal Nutrition lab, 30 metal pans were used, one for each broken tibia midshaft; each pan was individually labeled. The pans and bones were weighed together using a Mettler Toledo, Model AB204-S analytical balance scale (Switzerland). Following weighing, the bones were dried in a $110{ }^{\circ} \mathrm{C}$ oven for 24 hours. Once removed, they were placed in a dessicator for approximately one half hour in order to cool and to keep excess moisture from depositing. The bones and pans were then re-weighed using the previously mentioned analytical balance scale and their weights recorded. The bones were stored in the same metal pans they were dried in and then wrapped in plastic to keep them free of dust for three weeks awaiting 
completion of the experiment. In the final stages of the experiment, the bones were placed in the oven again at $110^{\circ} \mathrm{C}$ for 60 hours to remove any moisture that may have collected. The bones were removed from the oven and placed in the dessicator for one half hour in order to cool and keep excess moisture from depositing. The bones were weighed again using the same previously mentioned analytical balance and the weights recorded. After weighing each bone, the bones were placed in the container that was to be used for wet digestion and transferred to the Plant and Soil Sciences Lab in the Agricultural Science Building.

\section{BONE MINERAL COMPOSITION}

\section{Wet Digestion}

In the Plant and Soil Sciences Lab, wet digestion, using the Microwave Accelerated Reaction System 5 (MARS5), was done to dissolve the midshaft of the tibia (CEM Corporation, Matthews, NC). A solution of $5 \mathrm{~mL}$ of deionoized, distilled water $\left(\mathrm{H}_{2} \mathrm{O}\right)$ and $2 \mathrm{~mL}$ of Trace Metal Grade Nitric Acid $\left(\mathrm{HNO}_{3}\right)$ was poured into each vessel, HP-500 type, containing the bones. The vessels were placed in a carousel, and then the microwave. The program that contained the digestion parameters for the digestion of bones was called Bone Digestion, and used from the application menu of the MARS5 for the digestion. A total of fourteen samples were done per round of digestion with the time spent in the microwave approximately forty-five minutes. Once completed, the carousel was removed from the microwave and placed in the hood. The solutions were brought to volume in $25 \mathrm{~mL}$ volumetric flasks with a solution of $10 \%$ Trace Metal Grade Nitric Acid and 90\% distilled water. The solutions were then filtered through $110 \mathrm{~mm}$ diameter Whatman 42 filter paper. The filtered solution was placed in a $60 \mathrm{~mL}$ plastic bottle. Thirteen milliliters of the filtered solution was transferred from the plastic bottles to $14 \mathrm{~mL}$ plastic tubes in 
preparation for bone composition analysis. The remainder of the filtered solution was kept in the $60 \mathrm{~mL}$ plastic bottles and stored in the refrigerator.

\section{Composition Analysis}

The thirteen $\mathrm{mL}$ samples in plastic tubes were analyzed on a Perkin-Elmer 400 (P400) Inductively Coupled Argon Plasma Atomic Emission Spectrophotometer (ICP), (Wilton, CT). Samples were placed in the ICP machine and analyzed for calcium, magnesium and phosphorus levels. The ICP machine was set at a wavelength of $393.366 \mathrm{~nm}$ for calcium, $279.553 \mathrm{~nm}$ for magnesium, and 213.618nm for phosphorus.

\section{Statistical Analysis}

Analysis of variance (ANOVA) and regression analysis of the data was performed using Statistica Computer Software (StatSoft, Inc., 1999) to test the hypotheses. 


\section{RESULTS}

Under the present experimental conditions, with the animals under energy restricted conditions, analysis of variance (ANOVA) indicated that the mean values of bone length, weight, diameter, (Table 4), volume, density, fracture load (Table 5), and bone mineral composition (calcium, magnesium, and phosphorus) on per gram dry matter basis, (Table 6A, Table 6B), and bone mineral content on per volume basis (Table 6C) with the six different diets were not significant at $\mathrm{p} 0.05$ level. Therefore, all data were pooled. Using nitrogen excretion data from the earlier report, (Nomani et al., 2000), regression analysis indicated that there was no significant association (at $\mathrm{p}$ 0.05) between urinary nitrogen excretion and mineral composition, Table 7. Regression analysis also indicated that there was no significant association (at p 0.05) between bone mineral composition and breaking load of the midshaft of the tibia, Table 8, or between bone mineral composition and bone stiffness (displacement), Table 9.

The mineral composition was estimated on unit volume $\left(\mathrm{mm}^{3}\right)$ basis. Breaking load of the midshaft also was not associated with bone mineral composition on per unit volume basis. However, bone stiffness (displacement) at the force of 65 Newtons was significantly negatively associated with calcium $(\mathrm{r}-0.4, \mathrm{p}<0.05)$ and magnesium $(\mathrm{r}-0.5, \mathrm{p}<0.01)$ and phosphorus $(\mathrm{r}-0.51, \mathrm{p}<0.01)$, as shown in Figures 6-8.

Displacement was negatively associated $(\mathrm{r}-0.48, \mathrm{p}<0.01)$ with density, Figure 9 , and density was positively associated with calcium, magnesium, and phosphorus (r 0.83, 0.87, 0.93, respectively, $\mathrm{p}<0.01$ ) on unit volume basis, Figures 10-12 as shown in another model, Figure 13 . 
TABLE 4

PYSICAL PROPERTIES OF THE TIBIA (Whole Bone) WITH EXPERIMENTAL DIETS

MEAN $^{\star}$ STANDARD DEVIATION

\begin{tabular}{|c|c|c|c|c|c|c|c|c|c|}
\hline Parameter & $\begin{array}{c}\text { Diet } 1 \\
\text { Basal (B) }\end{array}$ & $\begin{array}{c}\text { Diet } 2 \\
\text { B+Coconut } \\
\text { oil }\end{array}$ & $\begin{array}{c}\text { Diet } 3 \\
\text { B+Olive oil }\end{array}$ & $\begin{array}{c}\text { Diet } 4 \\
\text { B+Corn } \\
\text { oil }\end{array}$ & $\begin{array}{c}\text { Diet } 5 \\
\text { B+Starch }\end{array}$ & $\begin{array}{c}\text { Diet } 6 \\
\text { B+High } \\
\text { Coconut oil }\end{array}$ & $\begin{array}{c}\mathrm{F} \\
\text { Value }\end{array}$ & $\begin{array}{c}\mathrm{P} \\
\text { Value }\end{array}$ & Significance \\
\hline Length, mm & $40.24^{ \pm} 1.21$ & $41.86 \pm 2.68$ & $41.48 \pm 0.915$ & $40.90 \pm 2.03$ & $41.50^{ \pm} 0.64$ & $41.29 \pm 0.34$ & 0.69 & 0.64 & NS* \\
\hline $\begin{array}{l}\text { Weight } \\
\text { (Wet), mg }\end{array}$ & $662 \pm 90$ & $654 \pm 121$ & $704 \pm 43$ & $657 \pm 78$ & $698 \pm 84$ & $743 \pm 83$ & 0.83 & 0.54 & NS \\
\hline $\begin{array}{l}\text { Diameter } \\
(\mathrm{ML})^{* *} \\
\text { Proximal } \\
\text { end, mm }\end{array}$ & $7.46^{ \pm} 0.72$ & $7.65^{ \pm} 0.8$ & $7.79^{ \pm} 0.39$ & $7.84^{ \pm} 0.20$ & $7.61^{ \pm} 0.3$ & $7.27^{ \pm} 0.3$ & 0.87 & 0.51 & NS \\
\hline $\begin{array}{l}\text { Diameter } \\
\text { (AP)*** } \\
\text { Proximal } \\
\text { end, mm }\end{array}$ & $8.14^{ \pm} 1.15$ & $8.54 \pm 1.1$ & $8.43^{ \pm} 0.78$ & $8.46^{ \pm} 0.57$ & $8.04^{ \pm} 0.96$ & $8.37^{ \pm} 0.47$ & 0.25 & 0.93 & NS \\
\hline $\begin{array}{c}\text { Diameter } \\
\text { (ML) } \\
\text { Midshaft, } \\
\text { mm }\end{array}$ & $2.52 \pm 0.14$ & $2.48 \pm 0.12$ & $2.50^{ \pm} 0.05$ & $2.38^{ \pm} 0.18$ & $2.50^{ \pm} 0.75$ & $2.41 \pm 0.14$ & 0.92 & 0.48 & NS \\
\hline $\begin{array}{c}\text { Diameter } \\
\text { (AP) } \\
\text { Midshaft, } \\
\text { mm } \\
\end{array}$ & $3.27^{ \pm} 0.27$ & $3.40 \pm 0.36$ & $3.23^{ \pm} 0.13$ & $3.34^{ \pm} 0.26$ & $3.52^{ \pm} 0.13$ & $3.30 \pm 0.31$ & 0.8 & 0.56 & NS \\
\hline $\begin{array}{l}\text { Diameter } \\
\text { (ML) Distal } \\
\text { end, mm }\end{array}$ & $6.07^{ \pm} 0.48$ & $6.14^{ \pm} 0.72$ & $6.45^{ \pm} 0.69$ & $6.00^{ \pm} 0.54$ & $6.23^{ \pm} 0.75$ & $5.93 \pm 0.66$ & 0.43 & 0.83 & NS \\
\hline $\begin{array}{l}\text { Diameter } \\
\text { (AP) Distal } \\
\text { end, mm }\end{array}$ & $4.04{ }^{ \pm} 0.38$ & $4.88^{ \pm} 1.62$ & $4.19^{ \pm} 0.31$ & $3.85^{ \pm} 0.37$ & $4.04^{ \pm} 0.5$ & $4.65^{ \pm} 1.24$ & 0.99 & 0.44 & NS \\
\hline
\end{tabular}

$* \mathrm{NS}=$ not significant at $\mathrm{p} 0.05$

**ML $=$ medial-lateral position

***AP $=$ anterior-posterior position 
TABLE 5

PYSICAL PROPERTIES OF THE TIBIA (Shaft**) WITH EXPERIMENTAL DIETS

$$
\text { MEAN }^{ \pm} \text {STANDARD DEVIATION }
$$

\begin{tabular}{|c|c|c|c|c|c|c|c|c|c|}
\hline Parameter & $\begin{array}{c}\text { Diet 1 } \\
\text { Basal (B) }\end{array}$ & $\begin{array}{c}\text { Diet 2 } \\
\text { B+Coconut } \\
\text { oil }\end{array}$ & $\begin{array}{c}\text { Diet 3 } \\
\text { B+Olive } \\
\text { oil }\end{array}$ & $\begin{array}{c}\text { Diet 4 } \\
\text { B+Corn oil }\end{array}$ & $\begin{array}{c}\text { Diet 5 } \\
\text { B+Starch }\end{array}$ & $\begin{array}{c}\text { Diet 6 } \\
\text { B+High } \\
\text { Coconut oil }\end{array}$ & $\begin{array}{c}\text { F } \\
\text { Value }\end{array}$ & $\begin{array}{c}\text { P } \\
\text { Value }\end{array}$ & Significance \\
\hline $\begin{array}{c}\text { Length, } \\
\text { mm }\end{array}$ & $19.17^{ \pm} 0.46$ & $20.06^{ \pm} 0.98$ & $\begin{array}{c}19.27^{ \pm} \\
081\end{array}$ & $19.5^{ \pm} 0.59$ & $20^{ \pm} 0.37$ & $19.99^{ \pm} 0.48$ & 1.89 & 0.13 & NS* \\
\hline $\begin{array}{c}\text { Weight } \\
\text { (Wet), mg }\end{array}$ & $337^{ \pm} 43$ & $356^{ \pm} 56$ & $339^{ \pm} 17$ & $338^{ \pm} 35$ & $351^{ \pm} 53$ & $367^{ \pm} 31$ & 0.43 & 0.82 & NS \\
\hline $\begin{array}{c}\text { Dry } \\
\text { Matter, } \\
\text { mg }\end{array}$ & $240^{ \pm} 0.02$ & $248^{ \pm} 0.03$ & $247^{ \pm} 0.01$ & $233^{ \pm} 0.02$ & $249^{ \pm} 0.03$ & $250^{ \pm} 0.01$ & 0.43 & 0.83 & NS \\
\hline $\begin{array}{c}\text { Volume, } \\
\text { mm }\end{array}$ & $126^{ \pm} 15$ & $137^{ \pm} 23$ & $124^{ \pm} 12$ & $126^{ \pm} 21$ & $142^{ \pm} 6$ & $129^{ \pm} 16$ & 0.96 & 0.46 & NS \\
\hline Density & $1.92^{ \pm} 0.19$ & $1.82^{ \pm} 0.15$ & $1.99^{ \pm} 0.1$ & $1.88^{ \pm} 0.23$ & $1.75^{ \pm} 0.16$ & $1.96^{ \pm} 0.2$ & 1.32 & 0.29 & NS \\
\hline $\begin{array}{c}\text { Fracture } \\
\text { Load of } \\
\text { Tibia, } \\
\text { Newtons }\end{array}$ & $95.72^{ \pm} 12.2$ & $96.24^{ \pm} 3.97$ & $93.03^{ \pm} 18.54$ & $90.28^{ \pm} 9.63$ & $84.40^{ \pm} 19.13$ & $97.15^{ \pm} 21.16$ & 0.5 & 0.78 & $\mathrm{NS}$ \\
\hline $\begin{array}{c}\text { Stiffness, } \\
\text { Displacement } \\
\text { of Tibia at } \\
65 \\
\text { Newtons, } \\
\text { mm }\end{array}$ & $0.858^{ \pm} 0.4$ & $0.903^{ \pm} 0.105$ & $0.672^{ \pm} 0.163$ & $1.045^{ \pm} 0.272$ & $0.939^{ \pm} 0.186$ & $1.298^{ \pm} 0.597$ & 1.9 & 0.13 & NS \\
\hline
\end{tabular}

$* \mathrm{NS}=$ not significant at $\mathrm{p} 0.05$

$* *$ Shaft $=$ Whole bone - proximal end - distal end 
TABLE 6A

TOTAL MINERAL CONTENT OF TIBIA SHAFTS WITH EXPERIMENTAL DIETS

$$
\text { MEAN }^{\star} \text { STANDARD DEVIATION }
$$

\begin{tabular}{|c|c|c|c|c|c|c|c|c|c|}
\hline Parameter & $\begin{array}{c}\text { Diet 1 } \\
\text { Basal (B) }\end{array}$ & $\begin{array}{c}\text { Diet 2 } \\
\text { B+Coconut } \\
\text { oil }\end{array}$ & $\begin{array}{c}\text { Diet 3 } \\
\text { B+Olive oil }\end{array}$ & $\begin{array}{c}\text { Diet 4 } \\
\text { B+Corn oil }\end{array}$ & $\begin{array}{c}\text { Diet 5 } \\
\text { B+Starch }\end{array}$ & $\begin{array}{c}\text { Diet 6 } \\
\text { B+High } \\
\text { Coconut oil }\end{array}$ & $\begin{array}{c}\text { F } \\
\text { Value }\end{array}$ & $\begin{array}{c}\text { P } \\
\text { Value }\end{array}$ & Significance \\
\hline $\begin{array}{c}\text { Calcium } \\
\text { Total, mg }\end{array}$ & $20.2^{ \pm} 0.38$ & $20.79^{ \pm} 0.79$ & $20.79^{ \pm} 0.48$ & $20.22^{ \pm} 0.63$ & $20.56^{ \pm} 0.43$ & $20.75^{ \pm} 0.41$ & 0.97 & 0.46 & NS* \\
\hline $\begin{array}{c}\text { Magnesium } \\
\text { Total, mg }\end{array}$ & $1^{ \pm} 0.09$ & $1.09^{ \pm} 0.13$ & $1.05^{ \pm} 0.03$ & $1.04^{ \pm} 0.1$ & $1.05^{ \pm} 0.09$ & $1.03 \pm 0.05$ & 0.49 & 0.78 & NS \\
\hline $\begin{array}{c}\text { Phosphorus } \\
\text { Total, mg }\end{array}$ & $30.96^{ \pm} 2.06$ & $32.75^{ \pm} 3.73$ & $32.72^{ \pm} 1.59$ & $30.3^{ \pm} 3.56$ & $32.16^{ \pm} 3.1$ & $32.66^{ \pm} 2.29$ & 0.69 & 0.64 & $\mathrm{NS}$ \\
\hline
\end{tabular}

*NS = not significant at $\mathrm{p} 0.05$

TABLE 6B

MINERAL CONTENT PER GRAM BONE BASIS OF TIBIA SHAFTS WITH EXPERIMENTAL DIETS

\section{MEAN $^{\star}$ STANDARD DEVIATION}

\begin{tabular}{|c|c|c|c|c|c|c|c|c|c|}
\hline Parameter & $\begin{array}{c}\text { Diet 1 } \\
\text { Basal (B) }\end{array}$ & $\begin{array}{c}\text { Diet 2 } \\
\text { B+Coconut } \\
\text { oil }\end{array}$ & $\begin{array}{c}\text { Diet 3 } \\
\text { B+Olive } \\
\text { oil }\end{array}$ & $\begin{array}{c}\text { Diet 4 } \\
\text { B+Corn oil }\end{array}$ & $\begin{array}{c}\text { Diet 5 } \\
\text { B+Starch }\end{array}$ & $\begin{array}{c}\text { Diet 6 } \\
\text { B+High } \\
\text { Coconut oil }\end{array}$ & $\begin{array}{c}\text { F } \\
\text { Value }\end{array}$ & $\begin{array}{c}\text { P } \\
\text { Value }\end{array}$ & Significance \\
\hline $\begin{array}{c}\text { Calcium, } \\
\text { mg/g of } \\
\text { bone** }\end{array}$ & $85.39^{ \pm} 4.95$ & $85.10^{ \pm} 9.42$ & $84.44^{ \pm} 4.21$ & $87.1^{ \pm} 5.82$ & $83.27^{ \pm} 7.39$ & $83.13^{ \pm} 3.92$ & 0.3 & 0.91 & NS \\
\hline $\begin{array}{c}\text { Magnesium, } \\
\text { mg/g of } \\
\text { bone** }\end{array}$ & $4.17^{ \pm} 0.23$ & $4.41^{ \pm} 0.28$ & $4.25^{ \pm} 0.17$ & $4.44^{ \pm} 0.16$ & $4.22^{ \pm} 0.26$ & $4.11^{ \pm} 0.18$ & 1.83 & 0.15 & NS \\
\hline $\begin{array}{c}\text { Phosphorus, } \\
\text { mg/g of } \\
\text { bone** }\end{array}$ & $129.23^{ \pm} 2.94$ & $132.94^{ \pm} 6.33$ & $132.72^{ \pm} 4.06$ & $129.7^{ \pm} 5.02$ & $129.44^{ \pm} 4.07$ & $130.71^{ \pm} 7.83$ & 0.47 & 0.8 & NS \\
\hline
\end{tabular}

$* \mathrm{NS}=$ not significant at $\mathrm{p} 0.05$

** For calculation, see Appendix 
TABLE 6C

MINERAL CONTENT PER UNIT VOLUME BASIS OF TIBIA SHAFTS WITH EXPERIMENTAL DIETS

MEAN ${ }^{\star}$ STANDARD DEVIATION

\begin{tabular}{|c|c|c|c|c|c|c|c|c|c|}
\hline Parameter & $\begin{array}{c}\text { Diet 1 } \\
\text { Basal (B) }\end{array}$ & $\begin{array}{c}\text { Diet 2 } \\
\text { B+Coconut } \\
\text { oil }\end{array}$ & $\begin{array}{c}\text { Diet 3 } \\
\text { B+Olive oil }\end{array}$ & $\begin{array}{c}\text { Diet 4 } \\
\text { B+Corn oil }\end{array}$ & $\begin{array}{c}\text { Diet 5 } \\
\text { B+Starch }\end{array}$ & $\begin{array}{c}\text { Diet 6 } \\
\text { B+High } \\
\text { Coconut oil }\end{array}$ & $\begin{array}{c}\text { F } \\
\text { Value }\end{array}$ & $\begin{array}{c}\text { P } \\
\text { Value }\end{array}$ & Significance \\
\hline $\begin{array}{c}\text { Calcium, } \\
\mathrm{mg} / \mathrm{mm}^{3}\end{array}$ & $0.16^{ \pm} .02$ & $0.16^{ \pm} 0.2$ & $0.17^{ \pm} 0.01$ & $0.16^{ \pm} 0.03$ & $0.14^{ \pm} 0.005$ & $0.16^{ \pm} 0.2$ & 0.74 & 0.47 & $\mathrm{NS}^{*}$ \\
\hline $\begin{array}{c}\text { Magnesium } \\
\mathrm{mg} / \mathrm{mm}^{3}\end{array}$ & $0.008^{ \pm} 0.0004$ & $0.008^{ \pm} 0.001$ & $0.008 \pm 0.0007$ & $0.008^{ \pm} 0.001$ & $0.007^{ \pm} 0.0006$ & $0.008^{ \pm} 0.001$ & 0.94 & 0.47 & $\mathrm{NS}$ \\
\hline $\begin{array}{c}\text { Phosphorus } \\
\mathrm{mg} / \mathrm{mm}^{3}\end{array}$ & $0.25^{ \pm} 0.03$ & $0.24^{ \pm} 0.03$ & $0.26^{ \pm} 0.01$ & $0.24^{ \pm} 0.03$ & $0.23^{ \pm} 0.02$ & $0.26^{ \pm} 0.03$ & 1.3 & 0.32 & NS \\
\hline
\end{tabular}

* Not Significant at p 0.05 
Table 7. ASSOCIATION BETWEEN NITROGEN EXCRETION AND BONE MINERAL COMPOSITION

\begin{tabular}{|l|c|c|c|}
\hline Minerals* & $\begin{array}{c}\text { Correlation Coefficient } \\
(\mathrm{r})\end{array}$ & P value & Significance** \\
\hline Calcium & 0.13 & 0.53 & NS \\
Magnesium & 0.23 & 0.27 & NS \\
Phosphorus & 0.2 & 0.34 & NS \\
\hline
\end{tabular}

* mineral, $\mathrm{mg} / \mathrm{g}$ bone (dry matter); nitrogen excretion, $\mathrm{mg}$ /day

** NS at P 0.05 level

Table 8. ASSOCIATION BETWEEN BONE MINERAL COMPOSITION AND MIDSHAFT BREAKING LOAD

\begin{tabular}{|l|c|c|c|}
\hline Minerals * & $\begin{array}{c}\text { Correlation Coefficient } \\
(\mathrm{r})\end{array}$ & P value & Significance** \\
\hline Calcium & -0.32 & 0.095 & NS \\
Magnesium & -0.22 & 0.24 & NS \\
Phosphorus & -0.14 & 0.46 & NS \\
\hline
\end{tabular}

* mineral, $\mathrm{mg} / \mathrm{g}$ bone (dry matter); breaking load in Newtons

** NS at P 0.05 level

Table 9. ASSOCIATION BETWEEN BONE MINERAL COMPOSITION AND BONE STIFFNESS

\begin{tabular}{|l|c|c|c|}
\hline Minerals* & $\begin{array}{c}\text { Correlation Coefficient } \\
(\mathrm{r})\end{array}$ & P value & Significance** \\
\hline Calcium & -0.02 & 0.94 & NS \\
Magnesium & -0.2 & 0.3 & NS \\
Phosphorus & -0.19 & 0.33 & NS \\
\hline
\end{tabular}

*mineral, $\mathrm{mg} / \mathrm{g}$ bone (dry matter); stiffness measured by displacement of bone in millimeters at 65 Newton

** NS at P 0.05 level 


\section{Figure 6}

\section{CALCIUM AND DISPLACEMENT}

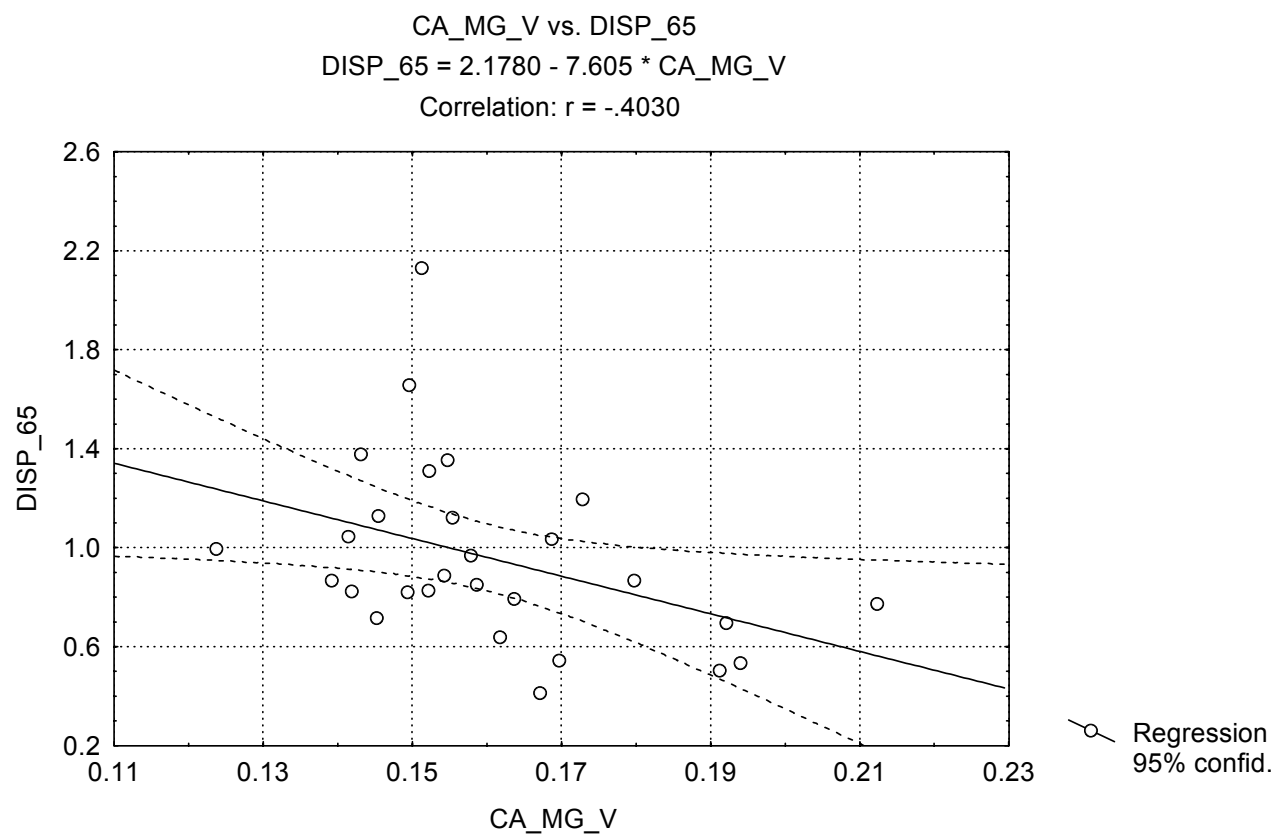

Association between bone shaft Calcium and stiffness

CA_MG_V, Calcium mg per cubic milliliter

displacement, DISP_65, in $\mathrm{mm}$, at the force of 65 Newton, $\mathrm{p}<0.04$. 


\section{Figure 7}

\section{MAGNESIUM AND DISPLACEMENT}

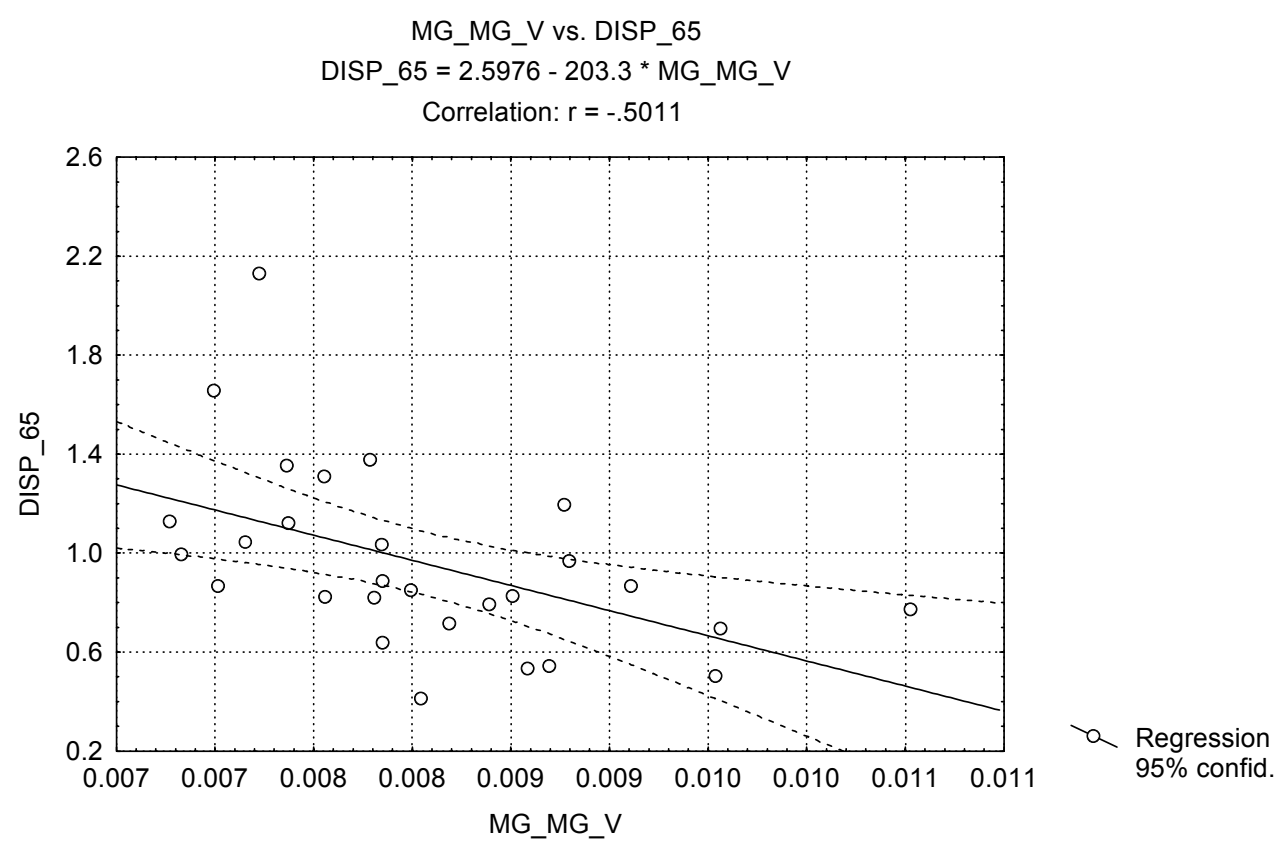

Association between bone shaft Magnesium and stiffness

MG_MG_V, Magnesium mg per cubic milliliter

displacement, DISP_65, in $\mathrm{mm}$, at the force of 65 Newton, $\mathrm{p}<0.01$. 
Figure 8

\section{PHOSPHORUS AND DISPLACEMENT}

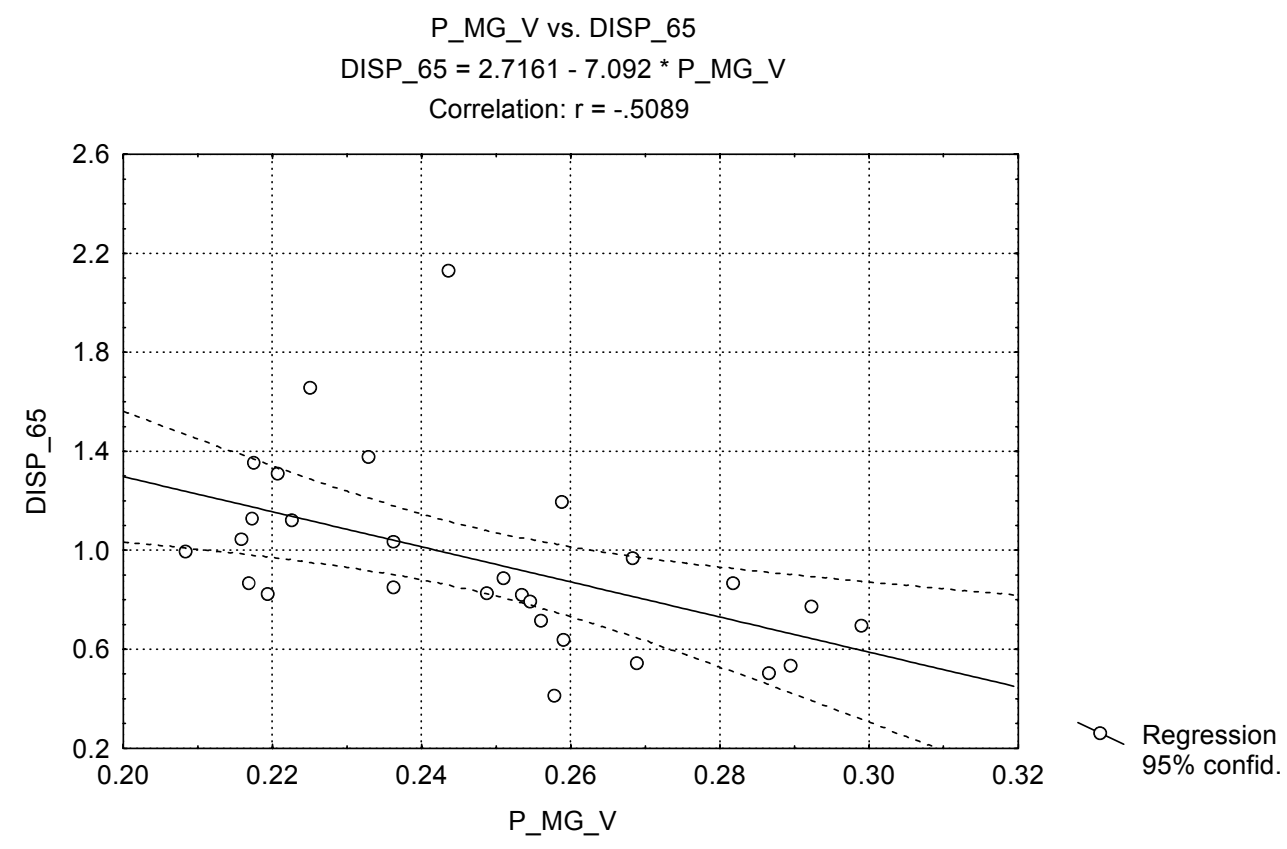

Association between bone shaft Phosphorus and stiffness

P_MG_V, Phosphorus mg per cubic milliliter

displacement, DISP_65, in $\mathrm{mm}$, at the force of 65 Newton, $\mathrm{p}<0.01$. 


\section{Figure 9}

\section{DENSITY AND DISPLACEMENT}

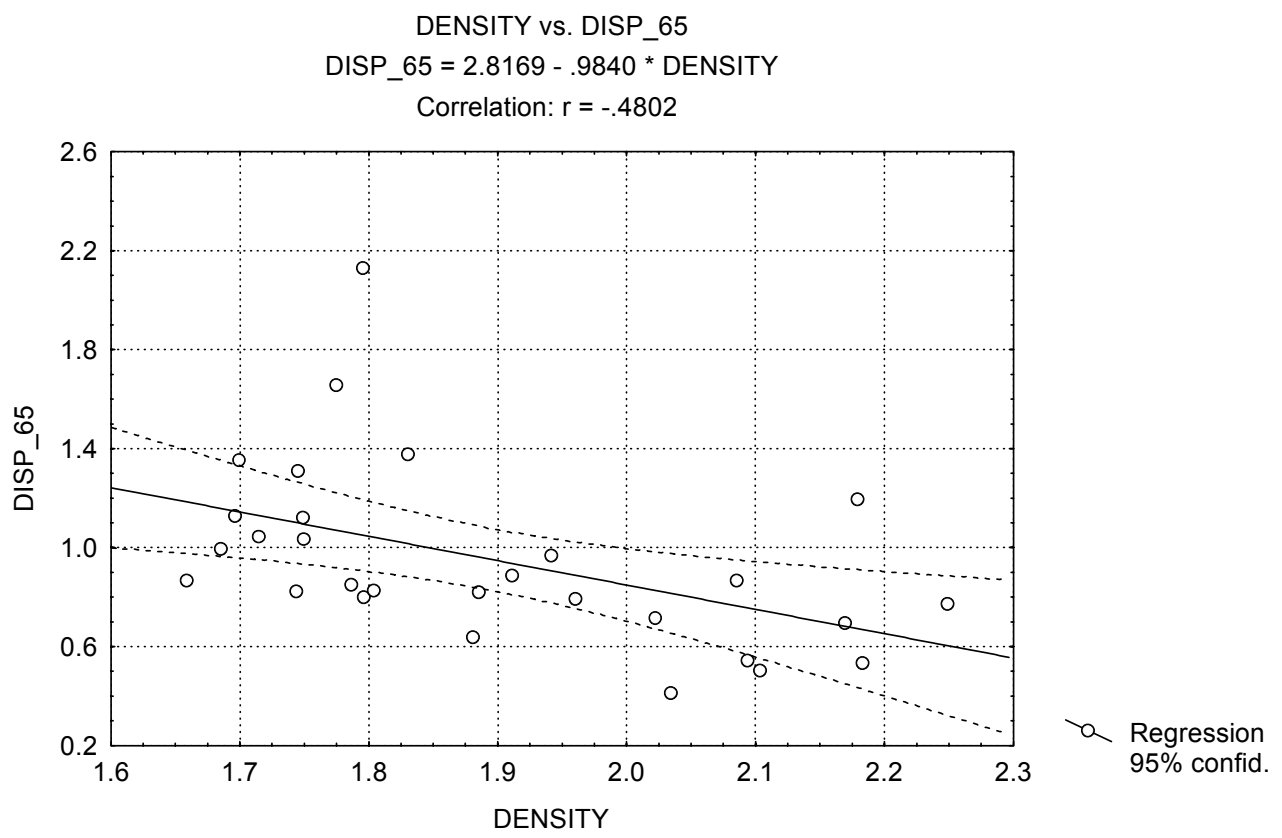

Association between bone shaft density and stiffness

DISP_65 - (displacement, $\mathrm{mm}$ ) at the force of 65 Newton, $\mathrm{p}<0.01$ 
Figure 10

\section{CALCIUM AND DENSITY}

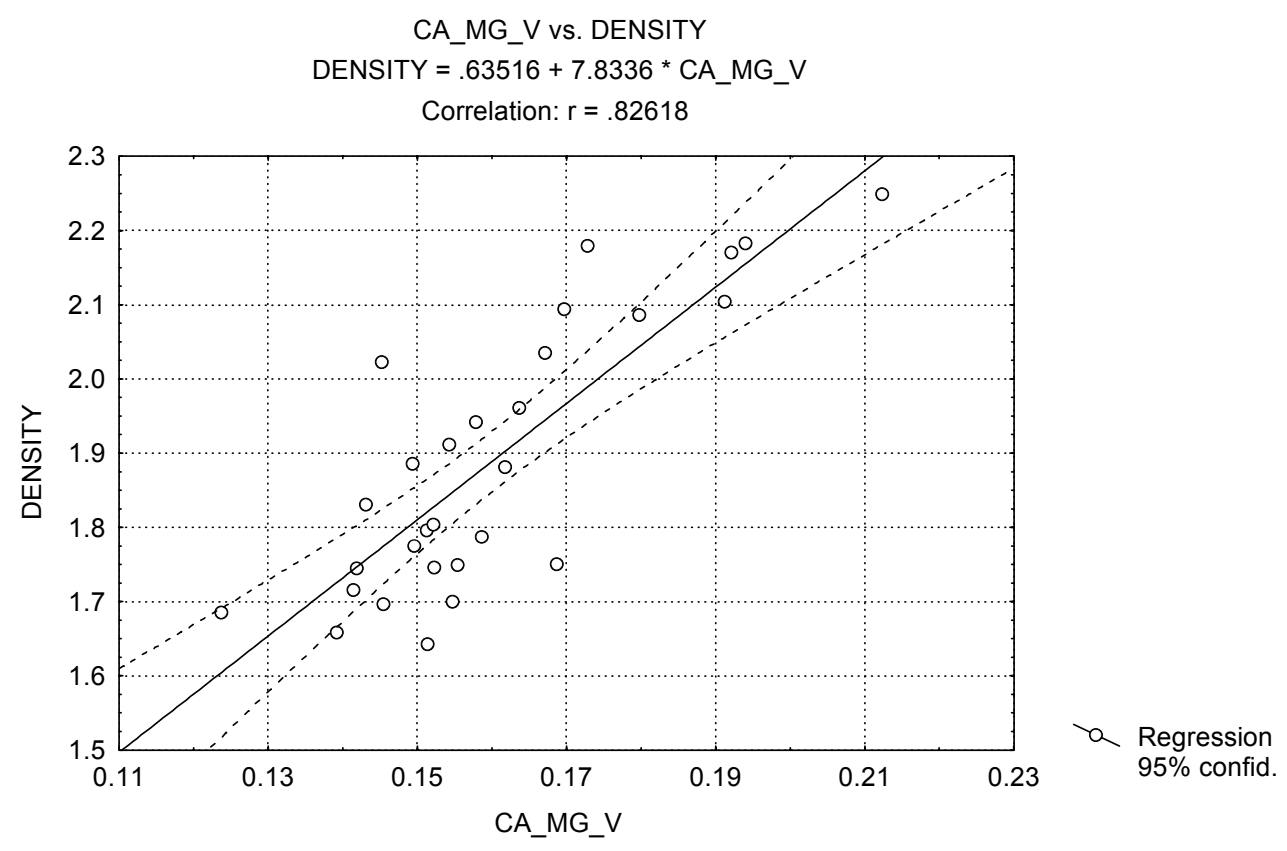

Association between bone shaft calcium and density, $\mathrm{p}<0.000$

(CA_MG_V), Calcium mg per cubic millimeter 
Figure 11

\section{MAGNESIUM AND DENSITY}

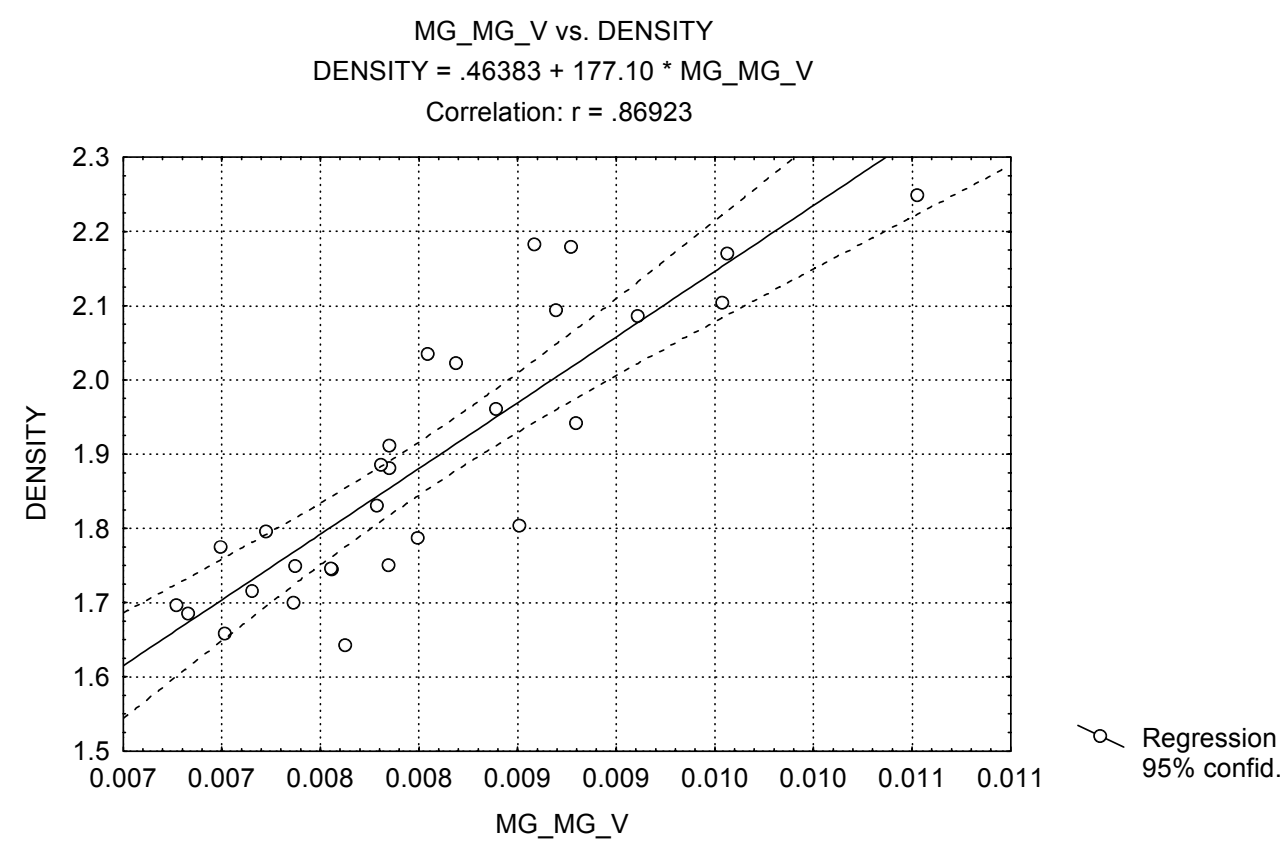

Association between bone shaft Magnesium and density, $\mathrm{p}<0.000$

(MG_MG_V), Magnesium mg per cubic millimeter 


\section{Figure 12}

\section{PHOSPHORUS AND DENSITY}

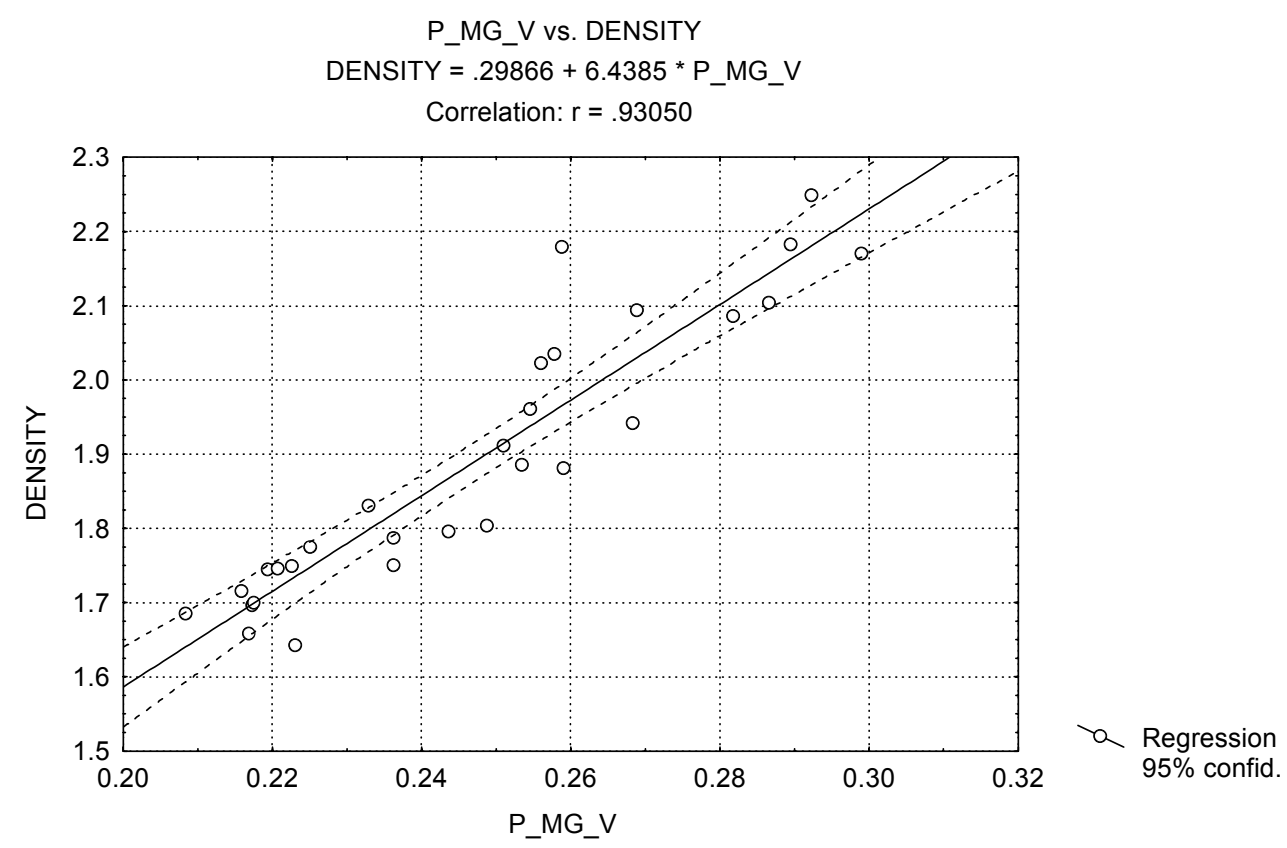

Association between bone shaft Phosphorus and density, $\mathrm{p}<0.000$

(P_MG_V), Phosphorus mg per cubic millimeter 
Figure 13

MODEL

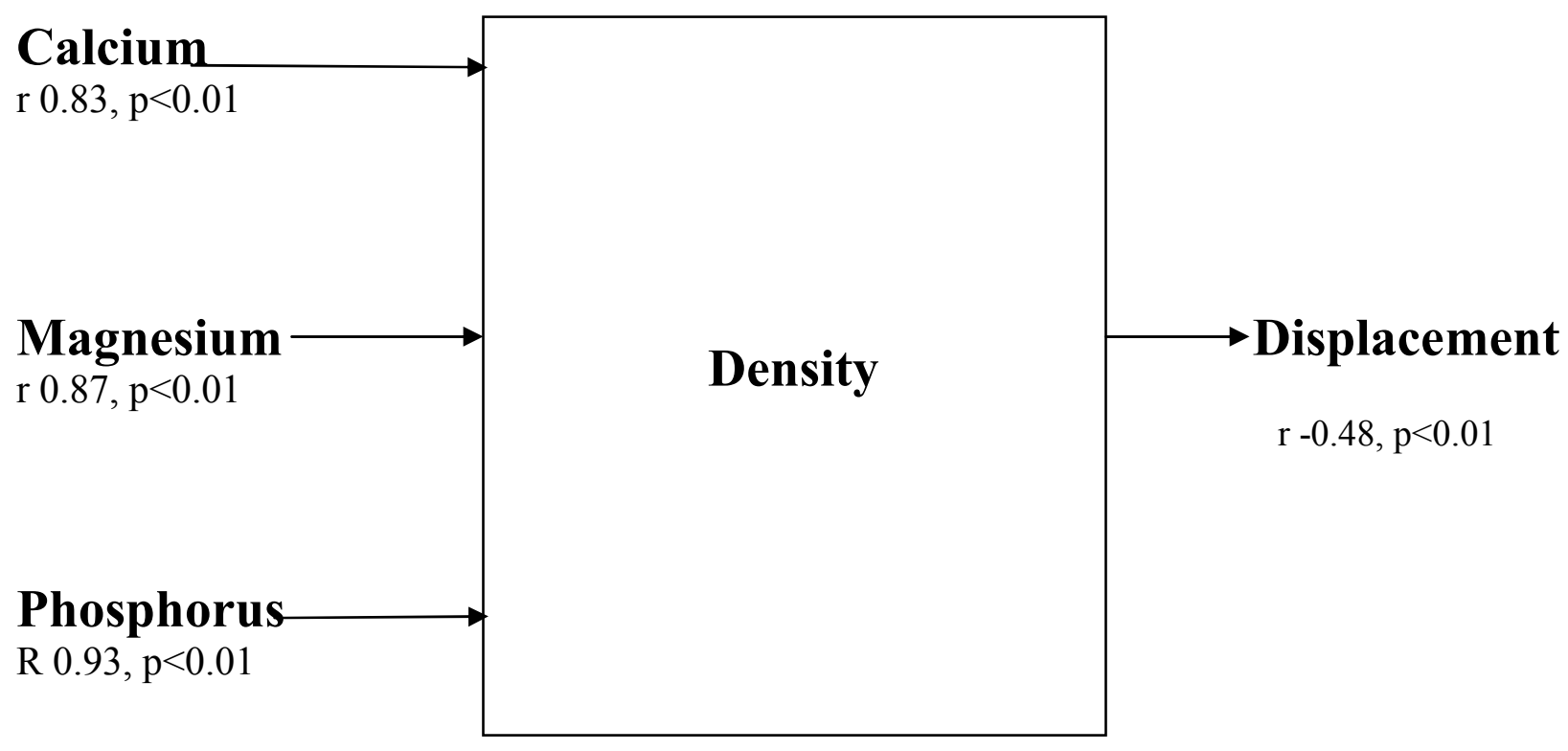




\section{DISCUSSION}

\section{Breaking Load}

Results from the previous experiment using the femur (Nomani et al., 2002a), indicated that head fracture load was positively associated with bone mineral composition, $\mathrm{mg} / \mathrm{g}$ weight basis. The head of the femur, however, is primarily composed of cancellous bone which is more sensitive to stimuli and more metabolically active. The non significant findings of the current

study are in agreement with those of Whol et al (1998) which also found no significant effect of consumption of a high fat diet on cortical bone mechanical properties, structure or mineral content. Whol et al (1999) concluded that cortical bone is not as sensitive to a high fat diet as cancellous bone. The findings of the present study are also supported by Smith et al (2000). Smith et al (2000) found that feeding growing rats a high fat diet had no effect on fracture force of the femur. The recent study conducted at West Virginia University is also in agreement with the findings of the present study (Nomani et al., 2002 , unpublished). Nomani et al (2002 unpublished) found that as the density of the tibia shaft decreased, the density of the distal end increased suggesting that the calcium content of the shaft was decreased and had moved to the distal end of the bone.

The non-significant results of the experiment on the tibia of these growing rats may also be due to the place the bone was cut. Though the bone was cut at the insertion point of the patellar tendon on the proximal end and $5 \mathrm{~mm}$ from the distal end, the remaining portion used for testing may have included cancellous bone as well as the desired cortical bone for testing. The following figure shows approximately where the bone was cut for this experiment: 


\section{Figure 14. Sites of bone end removal}

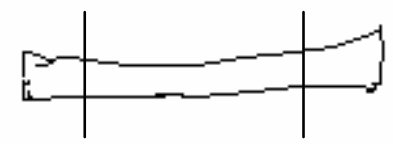

Due to the non-significance of the results, for future study, it may be beneficial to cut more of each end off to avoid cancellous bone becoming part of the cortical bone shaft. It is suggested that instead of cutting the bone into three pieces as shown above, it may be better to cut it into five pieces as shown in Figure 15. Part 1 and part 5 will be more representative of cancellous bone and part 3 more representative of cortical bone. Parts 2 and 4 will have a mixed representation of cancellous and cortical bone.

\section{Figure 15. Suggestions for sites of bone separation for future studies}

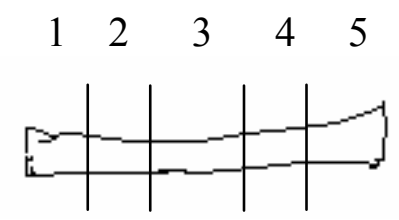

\section{Density and Displacement}

After estimating mineral composition on unit volume basis $\left(\mathrm{mm}^{3}\right)$, bone stiffness at the force of 65 Newtons was found to be significantly associated with calcium, magnesium, and phosphorus content of the bone. Density and breaking load were not associated. Additionally, displacement was negatively associated with density, Figure 13. In other words, denser means less displacement or less bending. Density was also positively associated with mineral composition on unit volume basis. The study by Talbott et al (2001) found that bone density of 
the femur and humerus in mature rats was positively correlated with calcium content of the bones. Our study relating to the bone density of the tibia is in agreement with the findings by Talbott et al (2001). The finding that mineral composition affected bone displacement but not breaking load may be due to the fact that the experimental animals were not adult and were still in the growth phase with the possibility of the long bones not being completely hardened or calcified.

\section{Summary and Conclusions}

The null hypothesis 1 , that urinary nitrogen excretion is not associated with bone mineral composition of the shaft of the tibia is accepted based on the findings of this study.

Also based on the findings of this study, the null hypothesis 2, that higher bone mineral composition (calcium, magnesium, phosphorus) is not associated with the breaking load of the midshaft of the tibia is accepted.

The third null hypothesis, that bone mineral composition on per weight basis does not affect bone stiffness is accepted as well. However, when mineral composition is considered on per unit volume basis this hypothesis is not accepted. In other words, mineral composition per unit volume basis did affect the stiffness of the tibia bone shaft. Displacement, bending, of the bone was negatively associated with bone shaft composition per unit volume.

It is concluded that for healthy physical properties of the tibia shaft, less bone displacement (bending), bone composition needs to be improved under energy restricted conditions. Further studies on energy supplementation along with calcium and vitamin D under energy restricted conditions are needed. 


\section{REFERENCES}

Abrams SA, Silber TJ, Esteban NV, Vieira NA, Stuff JE, Meyers R, Majd M, Yergey

AL. Mineral balance and bone turnover in adolescents with anorexia nervosa. J Pediatr.

$1993 ; 123: 326-331$.

AIN, American Institute of Nutrition. Report of the American Institute of Nutrition ad hoc committee on standards for nutritional studies. J Nutr. 1977;107:1340-1348.

American Psychiatric Association. 1994 Diagnostic and statistical manual of mental

disorders (DSM-IV), ed 4. Washington, DC:American Psychiatric Association.

Atteh JO, Leeson S, Julian RJ. Effects of dietary levels and types of fat on performance and mineral metabolism of broiler chicks. Poultry Science. 1983;62:2403-2411.

Atteh JO and Leeson S. Effects of dietary saturated or unsaturated fatty acids and calcium levels on performance and mineral metabolism of broiler chicks. Poultry Science. 1984;63:22522260.

Barzel US and Massey LK. Excess dietary protein can adversely affect bone. Journal of Nutrition. 1998;128(6):1051-1053.

Beals KA and Manore MM. Nutritional status of female athletes with subclinical eating disorders. J Am Diet Assoc. 1998;98:419-425.

Cooper C, Atkinson EJ, Hensrud DD, Wahner HW, O’Fallon WM, Riggs BL, Melton III LJ. Dietary protein intake and bone mass in women. Calcified Tissue International. 1996;58:320325.

El Ati J, Beji C, Danguir J. Increased fat oxidation during Ramadan fasting in healthy women: an adaptive mechanism for body-weight maintenance. Am J Clin Nutr. 1995;62(2):302307. 
Goldman L and Bennett JC. Cecil Textbook of Medicine $21^{\text {st }}$ ed. St. Louis, MO: W.B. Saunders Company;2000. 2306 p.

Hallak MH and Nomani MZA. Body weight loss and changes in blood lipid levels in normal men on hypocaloric diets during Ramadan fasting. Am J Clin Nutr. 1988;48:1197-1210.

Hannan MT, Tucker KL, Dawson-Hughes B, Cupples LA, Felson DT, Kiel DP. Effect of dietary protein on bone loss in elderly men and women: The Framingham Osteoporosis Study. Journal of Bone and Mineral Research. 2000;15(12):2504-2512.

Hernandez CJ, Beaupre GS, Carter DR. A model of mechanobiologic and metabolic influences on bone adaptation. J Rehabil Res Dev. 2000;37(2):235-244.

Holman RT, Adams CE, Nelson RA, Grater SJE, Jaskiewicz JA, Johnson SB, Erdman JW, Jr. Patients with anorexia nervosa demonstrate deficiencies of selected essential fatty acids, compensatory changes in nonessential fatty acids and decreased fluidity of plasma lipids. Journal of Nutrition. 1995;125:901-907.

Jacobs CR. The mechanobiology of cancellous bone structural adaptation. J Rehabil Res Dev. 2000;37(2):209-216.

Kerstetter JE, Mitnick ME, Gundberg CM, Caseria DM, Ellison AF, Carpenter TO, Insogna KL. Changes in bone turnover in young women consuming different levels of dietary protein. Journal of Clinical Endocrinology and Metabolism. 1999;84(3):1052-1055.

Kokkinos PP, Shaye R, Alam BS, Alam SQ. Dietary lipids, prostaglandin $\mathrm{E}_{2}$ levels, and tooth movement in alveolar bone of rats. Calcif Tissue Int. 1993;53:333-337.

Leonard MB, Zemel BS. Current concepts in pediatric bone disease. Pediatric Clinics of North America. 2002;49(1):143-173. 
Maislos M, Khamaysi N, Assali A, Abou-Rabiah Y, Zvili I, Shany S. Marked increase in plasma high-density-lipoprotein cholesterol after prolonged fasting during Ramadan. Am J Clin Nutr. 1993;57(5):640-642.

Martin E \& Guidos B. Editors. The Bantam medical dictionary $3^{\text {rd }}$ ed. New York: Market House Books Ltd; 1997. 534 p.

Meluzzi A, Sirri F, Tallarico N, Franchini A. Nitrogen retention and performance of brown laying hens on diets with different protein content and constant concentration of amino acids and energy. Br Poult Sci. 2001;42(2):213-217.

Nomani MZA, Forbes BA, Mossahebi P, Salaita CG, Loth MJ, Harvey JL, Brooks JL. Supplementation of energy restricted diets with coconut oil improves nitrogen balance without elevation of blood cholesterol levels. Journal of Food Science. 2000;65(6):1066-1069.

Nomani MZA, Forbes B, Bhumbla DK, Ashruf F, Khokar A, Norman TL, Fitch C, Mossahebi P. Improved nitrogen balance, bone mineral composition and higher fracture femoralneck load in rats with energy supplementation of energy restricted diets. FASEB Journal. 2002 a; 16(4):A624 (Abst.).

Nomani MZA, Goddard S, Romanchak M. Association between tibia shaft density and distal end density. $2002_{\mathrm{b}}$, unpublished.

Ricci RA, Heymsfield SB, Pierson RN, Stahl T, Chowdhury HA, Shapses SA. Moderate energy restriction increases bone resorption in obese postmenopausal women. Am J Clin Nutr. $2001 ; 73(2): 347-352$.

Riggotti NA, Nussbaum SR, Herzog DB, Neer RM. Osteoporosis in women with anorexia nervosa. N Engl J Med. 1984;311:1601-1606. 
Riggotti NA, Neer RM, Skates SJ, Herzog DB, Nussbaum SR. The clinical course of osteoporosis in anorexia nervosa. A longitudinal study of cortical bone mass. JAMA. 1991;265:1133-1138.

Rockwood CA, Green DP, Bucholz RW, Heckman JD. Editors. Rockwood \& Green's Fractures in Adults, $4^{\text {th }}$ ed. Philadelphia, PA: Lippincott-Raven Publishers;1996. 997 p.

Ruff CR and Hughes BL. Bone strength of height-restricted broilers as affected by levels of calcium, phosphorus, and manganese. Poultry Science. 1985;64:1628-1636.

Sakr AH. Fasting in Islam. J Am Diet Assoc. 1975;67:17-21.

Sanderson JP, Binkley N, Roecker EB, Champ JE, Pugh TD, Aspnes L, Weindruch R. Influence of fat intake and caloric restriction on bone in aging male rats. Journal of Gerontology: Biological Sciences. 1997;52A(1):B20-B25.

Sellmeyer DE, Stone KL, Sebastian A, Cummings SR. A high ratio of dietary animal to vegetable protein increases the rate of bone loss and the risk of fracture in postmenopausal women. American Journal of Clinical Nurtrition. 2001;73(1):118-122.

Smith EE, Ferguson VJ, Simske SJ, Gayles EC, Pagliassotti MJ. Effects of high fat or high sucrose diets on rat femora mechanical and compositional properties. Biomedical Sciences Instrumentation. 2000;36:385-390.

StatSoft, Inc. Statistica. Version 5.0 Tulsa, OK. 1999.

Steelman J and Zeitler P. Osteoporosis in Pediatrics. Pediatrics in Review. 2001;22(2):56-64.

Sweileh N, Schnitzler A, Hunter GR, Davis B. Body composition and energy metabolism in resting and exercising muslims during Ramadan fast. J Sports Med Phys Fitness. 1992;32(3):156-163. 
Talbott SM, Rothkopf MM, Shapses SA. Dietary restriction of energy and calcium alters bone turnover and density in younger and older female rats. Journal of Nutrition.1998;128:640645.

Talbott SM, Cifuentes M, Dunn MG, Shapses SA. Energy restriction reduces bone density and biomechanical properties in aged female rats. Journal of Nutrition. 2001;131:23822387.

Thomas CL. Editor. Taber's cyclopedic medical dictionary $18^{\text {th }}$ ed. Philadelphia, PA: F.A. Davis Company;1997. 2439 p.

Watkins Ba, Li Y, Allen KGD, Hoffmann WE, Seifert MF. Dietary ratio of (n-6)/(n-3) polyunsaturated fatty acids alters the fatty acid composition of bone compartments and biomarkers of bone formation in rats. J Nutr. 2000;130:2274-2284.

Whol GR, Loehrke L, Watkins BA, Zernicke RF. Effects of high-fat diet on mature bone mineral content, structure, and mechanical properties. Calcified Tissue International. 1998;63: 74-79.

Wong JCH, Lewindon P, Mortimer R, Sheperd R. Bone mineral density in adolescent females with recently diagnosed anorexia nervosa. International Journal of Eating Disorders. 2001;29:11-16.

Zipfel S, Seibel MJ, Lowe B, Beumont PJ, Kasperk C, Herzog W. Osteoporosis in eating disorders: A follow-up study of patients with anorexia and bulimia nervosa. Endocrinology and Metabolism. 2001;86(11):5227-5233. 


\title{
APPENDIX
}

\author{
Constant Volume X Dilution Factor $=\mathrm{mg} / \mathrm{kg}$ \\ Weight in grams dry matter of bone (ppm) \\ 1 part in $1,00,000$ \\ or \\ $1 \mathrm{mg}$ in $1,000,000 \mathrm{mg}$ \\ or \\ $1 \mathrm{mg} / 1,000 \mathrm{~g}$ \\ or \\ $1 \mathrm{mg} / \mathrm{kg}=\mathrm{ppm}$
}




\section{VITA}

Name..................................................... Romanchak

Parents.........................................John and Kathy Romanchak

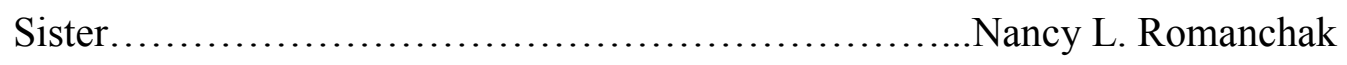

Birthplace.....................................Uniontown, Pennsylvania

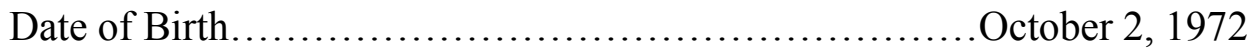

Education...................................... Dietetic Internship West Virginia University

Morgantown, WV

May, 2002

Bachelor of Science Information Systems/Finance Slippery Rock University Slippery Rock, PA

May, 1994 